\title{
Las riquezas de la Iglesia al servicio del poder monárquico: los empréstitos eclesiásticos en la Castilla del siglo $\mathrm{XV}^{1}$
}

\author{
Riches of the Church in the Service of Monarchical Power: Ecclesiastical \\ Loans in Fifteenth-Century Castile
}

\author{
Pablo Ortego Rico \\ Universidad Complutense. Madrid \\ pabloortego@ono.com
}

\begin{abstract}
RESUMEN
El presente estudio analiza desde una perspectiva política e ideológica los empréstitos establecidos con carácter extraordinario a lo largo del siglo XV por la Monarquía castellana sobre las riquezas atesoradas por las instituciones eclesiásticas del Reino. Para ello centraremos especialmente la atención en el empréstito ordenado por Isabel I en 1475-1476 en el marco del conflicto sucesorio con su sobrina Juana y Alfonso V de Portugal como expresión de la extensión de la soberanía regia al ámbito eclesiástico.
\end{abstract}

Palabras clave: Empréstito. Tesoro eclesiástico. Fiscalidad regia. Guerra de Sucesión. Iglesia. Monarquía. Castilla. Siglo XV.

\begin{abstract}
This study examines the extraordinary war loans the Castilian monarchy imposed during the fifteenth century upon the treasured riches preserved in the ecclesiastical institutions of the kingdom from a political and ideological perspective. It specifically focuses on the extraordinary loans ordered by Isabel I in 1475-1476 during the succession war against her niece Juana and Alfonso V of Portugal as an expression of the extension of royal sovereignty into the ecclesiastical sphere.
\end{abstract}

Key words: Loan. Ecclesiastical treasure. Royal taxation. Castilian Succession War. Church. Monarchy. Castile. Fifteenth century.

Sumario: 1. Introducción: la participación de la Monarquía en la fiscalidad y rentas eclesiásticas (siglos XIII-XV). 2. El recurso al empréstito eclesiástico en la baja Edad Media castellana. 3. Las tomas de plata y rentas de fábrica de 1475-1476 en el marco del conflicto sucesorio. 3.1. "Aquel remedio tanbién es remedio al tenplo". Los fundamentos legitimadores del empréstito. 3.2. Datos relativos al importe pagado y su destino efectivo. 3.3. Las resistencias a la exacción: los casos de Burgos y Sigüenza. 3.4. La lenta restitución del empréstito. 4. Conclusión.

1 Este trabajo cuenta con la ayuda económica de una beca FPU del Ministerio de Educación y se inscribe dentro del Proyecto de Investigación financiado por el Ministerio de Ciencia e Innovación $\mathrm{n}^{\circ}$ HAR2010-16762, titulado PRÁCTICAS DE CONSENSO Y DE PACTO E INSTRUMENTOS DE REPRESENTACIÓN EN LA CULTURA POLÍTICA CASTELLANA (SIGLOS XIII AL XV). Siglas y abreviaturas empleadas. AGS (Archivo General de Simancas); AHN (Archivo Histórico Nacional); BNE (Biblioteca Nacional de España); CCA (Cámara de Castilla); CMC, $1^{\text {a }}$ ép. (Contaduría Mayor de Cuentas, Primera época); EMR (Escribanía Mayor de Rentas); RGS (Registro General del Sello); PR (Patronato Real); f./ff. (folio/folios); leg. (legajo); mrs (maravedíes); Mss (manuscritos). 


\section{INTRODUCCIÓN: LA PARTICIPACIÓN DE LA MONARQUÍA EN LA FISCALIDAD Y RENTAS ECLESIÁSTICAS (SIGLOS XIII-XV)}

El tránsito paulatino de un Estado de carácter "domanial" o "territorial", en el que las relaciones políticas de carácter privado tienen asignado un mayor peso, a un Estado asentado sobre principios jurídicos que asignan a los elementos de carácter "público" un mayor peso tiene en la fiscalidad, tal y como ya estableció J. Schumpeter a comienzos del siglo XX, uno de sus escenarios principales. En este sentido, ya es un lugar común en la historiografía fiscal considerar la etapa que discurre entre mediados del siglo XIII y mediados del siglo XIV como un período "revolucionario" en función del surgimiento de nuevas formas impositivas y de gestión que sentarían los principios de los sistemas fiscales todavía vigentes en Castilla, con evidentes modificaciones, a comienzos de la Modernidad ${ }^{2}$. En todo este proceso, común por lo demás a la mayor parte de los territorios europeos, la percepción de rentas de origen eclesiástico como fuente extraordinaria de recursos y su fiscalización por parte del poder monárquico desempeñaría un papel fundamental ${ }^{3}$ en un contexto, como el bajomedieval, caracterizado por un incremento notable de las necesidades hacendísticas de los reyes y una redefinición de sus relaciones políticas con la Iglesia tendente a garantizar su inserción en las estructuras políticas del poder monárquico que, a su vez, amplía cada vez más sus competencias en el terreno eclesiástico ${ }^{4}$.

Como es bien sabido, en el caso castellano, esta participación en las rentas eclesiásticas - con algunos antecedentes previos de carácter todavía muy limitado- arrancaría de los años centrales del siglo XIII, momento en el cual quedaría configurada una imagen de la realeza que permitía justificar los intentos fiscalizadores a partir de la dirección de la lucha contra el infiel y de la capacidad del monarca para actuar en defensa de la Iglesia a través del privilegio o de la protección de sus fuentes de renta propias -especialmente el diezmo ${ }^{5}$ - . De esta forma surgirían en este momento, todavía con carácter extraordinario, nuevas figuras fiscales procedentes de diversos conceptos, entre las cuales destaca la participación de la Monarquía en el diezmo eclesiástico a partir del cobro de las dos novenas partes del tercio de fábrica, otorgadas con carácter extraordinario por primera vez en 1247 por el papa Inocencio IV a

${ }^{2}$ Ver este proceso en LADERO QUESADA, M.Á.: Fiscalidad y poder real en Castilla (1252-1369), Madrid, Real Academia de la Historia, 2011 ( $2^{\mathrm{a}}$ ed.). Las relaciones entre fiscalidad y Estado Moderno en GENÊT, J.-P. y LE MENÉ, M. (eds.), Genèse de l'Etat moderne: prélèvement et redistribution, Paris, Presses du CNRS, 1984.

3 Ver la síntesis de LADERO QUESADA, M.Á.: "Estructuras y políticas fiscales en la baja Edad Media europea", en Poteri economici e poteri politici. XIII Settimana di Studi, Istituto di Storia Economica Francesco Datini (Prato. 1998), Firenze, Le Monnier, 1999, pp. 369-410.

${ }_{4}$ NIETO SORIA, J.M.: Iglesia y génesis del Estado Moderno en Castilla (1369-1480), Madrid, Editorial Complutense, 1993, pp. 17-36; "La configuración eclesiástica de la realeza trastámara en Castilla (1369-1474). Una perspectiva de análisis”, En la España Medieval, 13 (1990), pp. 133-162.

5 LADERO QUESADA, M.Á.: Fiscalidad y poder real..., pp. 185-208. NIETO SORIA, J.M.: "La conflictividad en torno al diezmo en los comienzos de la crisis bajomedieval castellana (1250-1315)", Anuario de estudios medievales, 14 (1984), pp. 211-236; Iglesia y poder real en Castilla. El episcopado. 1250-1350, Madrid, Editorial Complutense, 1988, pp. 118-147. La imagen del rey castellano como rey "cristianísimo" que amparaba muchas de estas exacciones en NIETO SORIA, J.M.: Fundamentos ideológicos del poder real en Castilla (siglos XIII-XVI), Madrid, Eudema, 1988, pp. 79-84. 
Fernando III. Junto a las "tercias reales", cuya importancia resulta determinante en función de su conversión de facto en renta ordinaria de la Monarquía a lo largo del período Trastámara con un especial impulso en la época de Juan $\mathrm{II}^{6}$, encontramos otras formas de participación en la fiscalidad eclesiástica orientadas a la lucha contra el infiel cuyo especial componente religioso-político - caso de la bula de Cruzada- o su afectación directa al patrimonio y rentas eclesiásticas -caso de las décimas y subsidios-, implicaba a priori un mayor control por parte de los Pontífices, al menos en lo que se refiere a la concesión y formas de cobro, que facilitaría la perdurabilidad de su consideración como fuentes de renta extraordinaria ${ }^{7}$.

No obstante, una de las manifestaciones más características de este proceso de ampliación de las bases fiscales de la Monarquía, no tanto por su frecuencia sino por su especial significación política, viene constituida por las exigencias contributivas que los reyes castellanos realizaron sobre las rentas y patrimonio eclesiástico del Reino fuera de toda aprobación pontificia a partir de recursos de muy diversa índole -solicitud de contribuciones extraordinarias a obispos y cabildos, usurpaciones de bienes, empréstitos forzosos...- fundamentalmente como forma de financiación de empresas bélicas contra el infiel -lo que fue más habitual entre mediados del siglo XIII y mediados del XIV- o destinadas a la defensa del Reino en el transcurso de crisis políticas internas dotadas o no de una proyección exterior, esto último en mayor medida a lo largo de la época Trastámara. Más allá de su análisis coyuntural, estas contribuciones permiten analizar la participación del fisco del rey en el patrimonio eclesiástico a partir de la aplicación práctica de conceptos tendentes a reafirmar la dependencia e inserción de la Iglesia en un marco político regido por el principio de soberanía regia que comienza a fraguar y extenderse en sus aplicaciones territoriales y estamentales desde mediados del siglo XIII, con una incidencia plena en el campo de la fiscalidad ${ }^{8}$.

${ }^{6}$ NIETO SORIA, J.M.: Iglesia y génesis..., pp. 317-322. VILLARROEL GONZÁLEZ, Ó.: El rey y la Iglesia castellana. Relaciones de poder con Juan II (1406-1454), Madrid, Fundación Ramón Areces, 2011, pp. 323-326.

Sobre la bula de Cruzada sigue siendo imprescindible la consulta de la obra clásica de GOÑI GAZTAMBIDE, J.: Historia de la bula de la cruzada en España, Vitoria, Editorial del Seminario, 1958. Ver también las consideraciones sobre Cruzadas, subsidios y décimas en su aplicación específica al caso castellano entre mediados del siglo XIII y finales del XV en LADERO QUESADA, M.Á.: Fiscalidad y poder real..., pp. 196-202; La Hacienda Real de Castilla en el siglo XV, La Laguna, Publicaciones de la Universidad, 1973. Reed. La Hacienda Real de Castilla (1369-1504). Estudios y documentos, Madrid, Real Academia de la Historia, 2009, pp. 229-241. NIETO SORIA, J.M.: Iglesia y poder real..., pp. 123130; Iglesia y génesis..., pp. 322-337.

8 ISENMANN, E.: "Les théories du Moyen Age et la Renaissance sur les finances publiques", en R. Bonney (dir.), Systèmes économiques et finances publiques, Paris, Presses Univ. de France, pp. 3-35. Para el caso castellano ver ORTEGO RICO, P.: "Justificaciones doctrinales de la soberanía fiscal regia en la baja Edad Media castellana”, En la España Medieval, 32 (2009), pp. 113-138. 


\section{EL RECURSO AL EMPRÉSTITO ECLESIÁSTICO EN LA BAJA EDAD MEDIA CASTELLANA}

En este sentido, muchos de estos mecanismos de exacción extraordinaria establecidos al margen de la aprobación pontificia -en especial los empréstitos ${ }^{9}-$ basaban su legitimación última en la necesidad del Reino como comunidad corporativa sujeta a la autoridad (potestas) del monarca, concepto a partir del cual el bien de la colectividad o "bien común" se situaba por encima del bien de la parte. Como consecuencia de esta idea, se aceptaba el sacrificio de "la parte por el todo" traducido, en caso de necesidad urgente, en la pertenencia de los bienes de cada elemento integrado en este "todo" a la comunidad política de la cual formaba parte ${ }^{10}$, reflexión filosófico-política muy imbuida de los principios aristotélicos que permitía legitimar de forma genérica el establecimiento de empréstitos forzosos que afectasen a cualquier súbdito o natural sin atender en exceso a causas concretas más allá de la correspondencia de la necesidad que provocaba la exacción con la idea globalizadora de "bien común" orientada a garantizar la salvaguarda de los miembros de la comunidad política ${ }^{11}$.

Junto a estos fundamentos de orden político, la tratadística militar bajomedieval, basada en gran parte en las reflexiones de Flavio Vegecio (Epitome Rei Militaris), aportaría cauces legitimadores de índole mucho más práctico relacionados con el propio desarrollo de la guerra y su sentido último, al reconocer la capacidad del príncipe para recurrir al préstamo forzoso en aras de garantizar el abastecimiento y provisión del ejército, cuya intervención en favor de la seguridad de la tierra precisamente procuraría la defensa de los propios bienes de la comunidad. Así, en la traducción al castellano de estas reflexiones realizada por fray Alonso de San Cristóbal, probablemente durante el reinado de Enrique III ${ }^{12}$, se señala la necesidad de echar "enprestido" en caso de que "non abastaren los tributos de la tierra e del Reino" con objeto de dotar de provisiones el ejército "ca non ha en el mundo todo posision que sea segura nin bienes nin riquezas salvo si son defendidas por defension de armas"13.

9 No consideramos, por lo tanto, otros recursos tributarios como las contribuciones extraordinarias acordadas con el clero al margen de la aprobación pontificia.

10 ISENMANN, E.: op. cit., pp. 10-11. La concepción corporativa de la sociedad en relación con la idea de "fisco" fue abordada por múltiples pensadores y comentaristas escolásticos, como Agustín Triunfo o Tolomeo de Lucca. Una de las ideas que más trascendencia alcanzaría de cara a la legitimación de los desarrollos fiscales, y especialmente de una figura como los empréstitos, fue la asimilación de la comunidad -a la cual pertenecen los bienes de los miembros- con el propio fisco, aunque en la práctica el gobernante, como su personificación legal y legítima, ostentara su posesión. Ello no entra en contradicción con el reconocimiento de la propiedad privada de los bienes de los individuos, existente gracias a la ley, pero no como un derecho inherente al individuo. WILKS, M.: The problem of sovereignty in the later Middle Ages. The papal monarchy with Augustinus Triumphus and the publicists, Cambridge, University Press, 1964, pp. 177-183. También en POMINI, R.: La "causa impositionis" nello svolgimento storico della dottrina finanziaria, Milano, A. Giuffrè, 1951, p. 8.

${ }^{11}$ Sobre la idea de bien común ver NIETO SORIA, J.M.: Fundamentos ideológicos..., pp. 146-151.

12 Sobre la traducción y la crítica en relación con su autoría y datación ver ROCA BAREA, M.E.: "El Libro de la Guerra y la traducción de Vegecio por fray Alonso de San Cristóbal", Anuario de Estudios Medievales, 37/1, (enero-junio de 2007), pp. 267-270.

13 SAN CRISTÓBAL, A. DE: Libro de Vegecio de la caballería, M.T. Herrera y M.N. Sánchez (eds.), Salamanca, 2000, ff. 64r-64v. Una compilación anónima basada en el texto de fray Alonso de San 
Estas justificaciones doctrinales permitieron legitimar los empréstitos solicitados por los reyes castellanos a los distintos componentes que integraban la comunidad política del Reino entre los cuales, obviamente, se encontraba la Iglesia, inmersa a lo largo del período bajomedieval en un proceso de redefinición de sus relaciones con la Monarquía tendente a garantizar su apoyo a los proyectos regios a partir de la exigencia del cumplimiento de las obligaciones hacia el monarca que todo clérigo tenía como natural del Reino y leal súbdito ${ }^{14}$. No obstante, el respeto a las libertades y privilegios eclesiásticos que se presuponía a unos reyes "cristianísimos" hizo probablemente que, frente al mayor número de empréstitos solicitados a lo largo de este período al estamento ciudadano -representado fundamentalmente por los concejos-, tan solo se considerara la financiación extraordinaria a partir de requisas sobre el patrimonio eclesiástico en momentos de especial dificultad marcados por una manifiesta insuficiencia de los recursos fiscales ordinarios. Ya en 1343 Alfonso XI había tomado grandes cantidades de plata de ricos hombres y prelados, así como la plata de su propia casa, para el pago de las galeras de Génova que intervenían en la vigilancia costera del Estrecho posterior a la conquista de Algeciras en 1342, quizá una de las primeras muestra de este tipo de "tomas" con incidencia entre los miembros más destacados del estamento eclesiástico ${ }^{15}$, también realizadas por otras monarquías: por ejemplo, en 1356 el monarca aragonés Pedro IV el Ceremonioso ordenaba la requisa de gran cantidad de alhajas de oro y plata de los conventos de Valencia con objeto de sufragar los enormes gastos de la guerra que sostenía contra Pedro I de Castilla ${ }^{16}$.

A diferencia de estas noticias, los ejemplos de empréstito eclesiástico solicitados por los reyes de la dinastía Trastámara presentan un conjunto de características que permiten establecer ciertas diferencias con las formas de "toma" practicadas en tiempos anteriores. En primer lugar, su cobro a partir de la enunciación de un principio de "territorialidad" mucho más evidente, pues lejos de afectar a un conjunto determinado de prelados o dignidades a título individual, las exacciones más importantes solicitadas por los reyes durante el siglo XV recayeron sobre los bienes de la Iglesia castellana en su conjunto y como institución. A ello se suma la estrecha vinculación de estas peticiones con crisis políticas y militares completamente ajenas a la guerra contra el infiel, para cuya financiación habían quedado articuladas, al menos teóricamente, otras fórmulas extraordinarias de cesión de renta eclesiástica a partir de la

Cristóbal, datada hacia 1430, plantea la cuestión en los mismos términos. "La razon manda que digamos de la prouision, ca muchas vezes se pierde la hueste antes por mengua de aquella que por pelea que mas cruel es la fanbre que el fierro; que gran golpe et gran dardo es contra los enemigos que tu ayas prouision abasto et el los mengua. Por ende todo rey o principe con gran cuydado deue buscar las prouisiones por las comarcas con tiempo et siempre en mayor copia que es menester, et sy por venta los tributos de en enprestidos o de otra manera non bastaren prouisiones et le cumplan todas las cosas que son menester; que possessiones nin bienes et riquezas non pueden ser seguras, saluo sy son defendidas por armas, quanto mas que muchas vezes acaesçe por mengua de la dicha prouision doblarse la neçessidat et menester, et la guerra durar mas". Libro de la guerra, L. de la Torre (ed.), Nueva York-París, 1916, Cap. VII.

${ }^{14}$ NIETO SORIA, J.M.: Iglesia y génesis..., p. 414.

15 LADERO QUESADA, M.Á.: Fiscalidad y poder real..., p. 219.

16 SÁNCHEZ-LAFUENTE GÉMAR, R.: "La platería en las catedrales. Del tesoro medieval a la acumulación contrarreformista", en J. Rivas Carmona (coord.), Estudios de Platería, Murcia, Universidad de Murcia, 2005, p. 500. 
concesión pontificia de décimas y subsidios sobre los frutos de cada diócesis o de indulgencias de Cruzada. Finalmente, el propio carácter de estas exacciones forzosas, fuera del alcance del estamento ciudadano o de la negociación con el Pontificado, hacía que, de hecho, pasaran a quedar incluidas dentro de las prerrogativas exclusivas del rey ${ }^{17}$ como elemento vinculado a la concepción en términos absolutos de su poder que comenzaba a fraguar. De ahí que su grado de aceptación permita valorar, en cierta medida, la adhesión de la Iglesia del Reino al proyecto monárquico en función de la dimensión propagandística que la petición de un empréstito adquiría, toda vez que una toma de posición favorable hacia la exacción por parte de un grupo de poder como el eclesiástico contribuía notablemente a sancionar la virtud y "necesidad" de la causa argumentada para legitimar el tributo, y por lo tanto podía llegar a alcanzar un efecto multiplicador de la confianza en el poder político que ordenaba su imposición ${ }^{18}$.

Estas circunstancias se perciben de forma muy clara en los dos empréstitos forzosos de bienes eclesiásticos más importantes exigidos por los reyes castellanos a lo largo del siglo XV:

- En primer lugar, el establecido por Juan II en 1429 en una coyuntura marcada por el breve conato de guerra entre Castilla y Aragón en el contexto conflictivo desencadenado por las luchas políticas sostenidas entre don Álvaro de Luna, privado de Juan II, y los infantes de Aragón, primos del rey ${ }^{19}$.

- En segundo lugar, el ordenado por Isabel I durante los años 1475-1476, en los momentos más críticos de la guerra por el trono castellano sostenida contra su sobrina Juana y Alfonso V de Portugal, al que dedicaremos el grueso principal del trabajo en función de la mayor disponibilidad documental con que contamos para llevar a cabo un análisis integral.

La práctica común asociada a estos dos préstamos partía de la exigencia formulada desde el poder regio al conjunto de las iglesias y monasterios del Reino para que entregasen parte de la plata y ornamentos litúrgicos atesorados con objeto de acuñar moneda destinada al pago de las tropas movilizadas o a la restitución de los adelantos de numerario realizados por otros prestamistas. Obviamente, ello tenía un evidente trasfondo ideológico en razón del especial simbolismo que encerraba la medida pues, al afectar a objetos sagrados destinados al culto, la práctica podía llegar a ser considerada como un acto sacrílego, tal y como se reconocía tanto en la legislación canónica y sinodal, sobre la cual nos ocuparemos más adelante, como en la tratadística de la época relativa a la figura del rey tirano. Por ejemplo, en la Caida de Príncipes de Pero López de Ayala, traducción realizada en 1402 del De casibus virorum illustrium de

17 OLIVERA SERRANO, C.: "Empréstitos de la corona de Castilla bajo la dinastía Trastámara", Hispania, 51 (1991), pp. 317-327, especialmente p. 320 y para el empréstito de 1429 pp. 324-325.

18 Tal y como se ha señalado para el caso del empréstito de 1476. SANZ SANCHO, I.: "El empréstito de 1476 en las iglesias de los obispados de Jaén y Córdoba", En la España Medieval. V Estudios en Memoria del Professor D. Claudio Sánchez-Albornoz, 2 (1986), p. 1196.

${ }_{19}$ Las circunstancias políticas de este episodio en PORRAS ARBOLEDAS, P.A.: Juan II, rey de Castilla y León (1406-1454), Gijón, Ediciones Trea, 2009, pp. 131-143. 
G. Boccaccio ${ }^{20}$, la descripción de la figura del emperador Nerón -uno de los modelos de tirano propuestos por el humanista florentino-, incluía como muestra de su escasa devoción, vinculada a la prodigalidad y a la avaricia, el robo de joyas, oro y plata de los templos ${ }^{21}$. Sin embargo, los ordenamientos jurídicos y la cronística áulica de la época trataron de consolidar un marco legal partiendo siempre del reconocimiento de la excepcionalidad de estas medidas con objeto de asignar cauces legitimadores a un procedimiento de exacción que podía llegar alcanzar la consideración de atentado contra la libertas de la Iglesia. Así, sobre la base precedente de los ordenamientos dados en las Cortes de Burgos de 1409 y de Zamora de 1432, las Ordenanzas Reales de Montalvo (publicadas en 1484) señalan cómo "la plata e bienes de las iglesias el rey non los debe nin puede tomar, pero si acaesçiere tienpo de guerra o de gran menester, que el rey pueda tomar la tal plata, tanto que después la restituya enteramente sin alguna diminuçión a las iglesias"22.

Precisamente, el caso de empréstito exigido por Juan II en 1429 permite apreciar la falta de correspondencia entre el ideal plasmado en los ordenamientos jurídicos y la realidad en la cual se movía la devolución de las cantidades requisadas ${ }^{23}$. Así, para este año contamos con noticias de las tomas realizadas por el rey en los tesoros monásticos de Santa María de Guadalupe y de San Benito de Valladolid ${ }^{24}$, que actuaban -al igual que los de muchas otras instituciones religiosas- como depósito de bienes, dinero y joyas ${ }^{25}$. En el caso de San Benito, la requisa, que alcanzaría un elevadísimo valor ( 20.000 o 25.000 florines que, traducidos en moneda de cuenta, supondrían 1.070.000-1.337.500 $\mathrm{mrs}^{26}$ ), fue restituida -a decir de Pedro Carrillo de Huete- con cargo al servicio ("pedido e monedas") otorgado por las Cortes en 1429. Por lo demás, el cronista trataría de ofrecer en su relato una imagen de moderación en relación con la "toma" ordenada al señalar la renuncia del rey a requisar la plata "e otras joyas" depositadas en el monasterio ${ }^{27}$.

20 Sobre la obra y la traducción castellana ver NAYLOR, E.W.: "Sobre la traducción de La caída de príncipes de don Pedro López de Ayala”, en R. Beltrán, J.L. Canet y J.L. Sierra (eds.), Historias y ficciones. Coloquio sobre literatura del siglo XV, Valencia, Universitat de València, 1992, pp. 141-156.

21 "diremos de la su poca deuoçion que avn los tenplos de los sus dioses todos los forçaua e robaua las joyas que de plata e de oro alli fallaua". LÓPEZ DE AYALA, P.: Caída de príncipes, E.W. Naylor (ed.), Madison, 1995, f. 199v.

22 Ordenanzas Reales de Castilla, Madrid, Imprenta de Josef Doblado, 1779. Libro 1, Título 2 , ley 12. MARÍA E IZQUIERDO, M.J.: Las fuentes del Ordenamiento de Montalvo, Madrid, Dykinson, 2005 , p. 89.

23 Sobre el empréstito ver VILLARROEL GONZÁLEZ, Ó.: op. cit., pp. 320-322.

24 BRASAS EGIDO, J.C.: La platería vallisoletana y su difusión, Valladolid, Institución Cultural Simancas-Diputación Provincial de Valladolid, 1980, p. 78.

25 Por ejemplo, en San Benito de Valladolid se guardaban parte de los bienes del contador mayor Alonso de Robles. VILLARROEL GONZÁLEZ, Ó.: op . cit., pp. 320-321. Por su parte, el prior del monasterio de San Bartolomé de Lupiana acogería como albacea las joyas que habían pertenecido a la duquesa de Arjona Aldonza de Mendoza, reclamadas por su hermanastro el marqués de Santillana Íñigo López de Mendoza en 1441. AHN, Clero, leg. 2151, sin f.

26 A 53 mrs y medio el florín.

27 "E otro dia, domingo, tomó enprestados los tesoros de San Venito, de los que ay lo tenían ascondido, que podían ser todos fasta veinte o veinte y cinco mil florines, sin plata e otras joyas, las quales no quiso tomar". CARRILLO DE HUETE, P.: Crónica del Halconero de Juan II, J.M. Carriazo 
Otros documentos certifican el cobro del empréstito de 1429 en el obispado de Burgos, cuya recaudación quedaría a cargo de un prelado de la máxima confianza del rey como Pablo de Santa María; el obispado de Jaén, donde todavía se recaudaba en 143028; o el arzobispado de Toledo. En este último caso, la relación de préstamos cobrados en nombre del rey por Álvar García de Santa María ${ }^{29}$ incluye distintas cantidades procedentes de instituciones eclesiásticas entre las cuales se encuentra cierta plata "del sagrario" de la catedral toledana destinada a la ejecución de las mandas testamentarias del arzobispo don Sancho [de Rojas] apreciada en $31.680 \mathrm{mrs} ; 55$ marcos y 7 ochavas de plata que un clérigo del arzobispo de Toledo tenía en depósito para cumplir un testamento (25.900 mrs); y finalmente, 30 marcos de plata "del sagrario" de escasa calidad -fue tasada a $450 \mathrm{mrs} / \mathrm{marco}$, cuando lo habitual era una tasación a $470 \mathrm{mrs} / \mathrm{marco}$ - pertenecientes a la obra de la catedral (13.500 mrs). A todo ello se suman los 14.000 mrs tomados, según repartimiento, de algunos monasterios del arzobispado de Toledo en ciertas "prendas y ornamentos" de sus iglesias; y los 130.500 mrs que el cabildo catedralicio toledano "se ofreció a prestar", lo cual parece reflejar el apoyo explícito de la institución capitular a la línea política de hostilidad hacia el partido aragonés marcada por el privado don Álvaro de Luna, aunque desconocemos las presiones directas o indirectas que pudieron mediar para la satisfacción efectiva del préstamo. En suma, las cantidades de origen eclesiástico percibidas ascendían a $215.580 \mathrm{mrs}$, lo cual suponía casi un 90 \% del total recibido por Álvar García de Santa María (247.090 mrs), que también incluía otros préstamos realizados por laicos. Ello pone de manifiesto la importancia de la contribución de la Iglesia a la financiación extraordinaria del conflicto bélico con Aragón, habida cuenta de las garantías de cobro rápido que ofrecían las grandes cantidades de plata que formaban parte de los tesoros y depósitos eclesiásticos.

No obstante, a pesar de la obligatoriedad de la devolución de estos empréstitos prometida por el rey y reconocida en los ordenamientos jurídicos aprobados en Cortes, los procuradores de las ciudades del Reino recordarían en 1430, 1431, 1432, 1435 y 1442 al monarca la necesidad de llevar a cabo la restitución de la plata tomada y las cantidades entregadas por los concejos que seguían sin ser reembolsadas ${ }^{30}$, a lo cual Juan II respondería en las Cortes de Valladolid de 1442 de forma claramente evasiva $^{31}$. Quizás, los representantes ciudadanos trataban de arrancar del monarca un compromiso que incluyese la devolución de las cantidades prestadas a partir de su vinculación con la restitución de la plata tomada de las iglesias, cuyo componente religioso constituía un argumento enormemente favorable para una reposición que no terminaba de llegar. En otros casos fueron los propios eclesiásticos los encargados de elevar sus protestas: por ejemplo, tal y como señala Ó. Villarroel, en 1445 Rodrigo Sánchez de Arévalo era comisionado por el cabildo burgalés para solicitar la resti-

(ed.), Madrid, Espasa-Calpe, 1946 [Reed. Granada, Editorial Universidad de Granada, 2006], Cap. XVI, p. 33.

28 VILLARROEL GONZÁLEZ, Ó.: op. cit., pp. 804-805.

${ }^{29}$ AGS, EMR, leg. 1, ff. 99-102.

30 Algunas cantidades fueron reembolsadas de forma relativamente rápida. Por ejemplo, Álvar García de Santamaría recibió orden de devolver a los monasterios del arzobispado de Toledo los ornamentos de sus iglesias que había recibido por valor de 14.000 mrs. AGS, EMR, leg. 1, ff. 99-102.

${ }^{31}$ NIETO SORIA, J.M.: Iglesia y génesis..., p. 339. 
tución del dinero prestado, reintegrado finalmente de su patrimonio por el obispo Alonso de Cartagena en $1446^{32}$.

\section{LAS TOMAS DE PLATA Y RENTAS DE FÁBRICA DE 1475-1476 EN EL MARCO DEL CONFLICTO SUCESORIO}

A partir de 1429 no se conocen nuevos casos de incautaciones o empréstitos ordenados sobre la totalidad de las iglesias del Reino, aunque sí de préstamos realizados por algunas diócesis con carácter particular ${ }^{33}$ y de otras cantidades sacadas puntualmente de algunas instituciones religiosas ${ }^{34}$. Hay que esperar, por lo tanto, al inicio del conflicto sucesorio que se abría a la muerte de Enrique IV en diciembre de 1474 para contar con datos relativos a un nuevo empréstito eclesiástico general, esta vez sobre la mitad de la plata y oro de los tesoros de las iglesias y monasterios del Reino y la mitad de las rentas destinadas a la conservación de sus fábricas durante un año, medida ordenada durante el bienio 1475-1476 por Isabel I con objeto de solventar los apuros financieros que atravesaba su causa política tras la invasión del Reino llevada a cabo por Alfonso V de Portugal ${ }^{35}$.

Las circunstancias de este empréstito, mucho mejor documentado tanto a nivel cronístico como documental que el de 1429 , permiten una valoración más completa de aspectos como los argumentos legitimadores expresados y la propaganda realizada por el partido isabelino para facilitar su aceptación; la gestión de su cobro; la correspondencia de los fines aducidos con los gastos realizados con cargo a las cantidades recaudadas; las resistencias al pago planteadas por la clerecía y su instrumentalización política; y, finalmente, la forma de restitución de las cantidades tomadas en función del compromiso inicial adquirido por los reyes ${ }^{36}$.

32 VILLARROEL GONZÁLEZ, Ó.: op. cit., p. 805.

${ }^{33}$ Por ejemplo, en 1432 Burgos prestaba a Juan II 535 marcos y medio de plata, y en 1444 Palencia entregaba al monarca 359 doblas. Ibídem, p. 321.

${ }_{34}$ Enrique IV cobraría del monasterio burgalés de Cardeñosa, a través de la mediación de su contador mayor Diego Arias Dávila, 400.000 mrs de préstamo y 18.000 .000 mrs de donativo voluntario NIETO SORIA, J.M.: Iglesia y génesis..., p. 339.

35 El período que media entre la proclamación de Isabel en Segovia y el asentamiento definitivo en el trono ha sido abordado desde el punto de vista de la propaganda política por CARRASCO MANCHADO, A.I.: Isabel I de Castilla y la sombra de la ilegitimidad. Propaganda y representación en le conflicto sucesorio (1474-1482), Madrid, Sílex, 2006. El relato cronológico de los hechos en AZCONA, T. DE: Isabel La Católica. Estudio crítico de su vida y su reinado, Madrid, Biblioteca de Autores Cristianos, 1993 ( $3^{\mathrm{a}}$ ed.), pp. 237-348. SUÁREZ FERNÁNDEZ, L.: Los Reyes Católicos. La conquista del trono, Madrid, Ediciones Rialp, 1989.

36 Visión general del empréstito en AZCONA, T. DE: op. cit., pp. 299-304. El caso de las diócesis de Jaén y Córdoba ha sido abordado con detalle por SANZ SANCHO, I.: op. cit., pp. 1175-1196. 


\section{1. "AQUEL REMEDIO TANBIÉN ES REMEDIO AL TENPLO"LOS FUNDA- MENTOS LEGITIMADORES DEL EMPRÉSTITO}

Es evidente que las circunstancias políticas bajo las cuales fue ordenado este empréstito resultan completamente diferentes a las observadas en la toma de plata llevada a cabo en 1429 pues, en una situación de división del Reino en dos obediencias como la vivida en 1475, la medida decretada por Isabel era susceptible de chocar, a pesar de los denodados esfuerzos por crear unas condiciones de consenso que la hiciesen más tolerable, con la oposición de parte de la clerecía castellana que apoyaba a la facción portuguesa o que directamente no estaba dispuesta a permitir la usurpación de los bienes destinados al culto y conservación de las iglesias. A pesar de que fray Hernando de Talavera, confesor de la reina y prior de Prado, reconocía en una carta escrita en septiembre de 1477 la "paternidad" de la medida ${ }^{37}$-asumida también por parte del Cardenal Pedro González de Mendoza ${ }^{38}$-, según Hernando del Pulgar, la decisión de tomar la plata fue acordada en el Consejo Real, cuyas deliberaciones tratarían de aportar cauces legitimadores de muy diversa índole destinados a contrarrestar, por un lado, la concepción sacrílega existente en torno a la puesta en práctica de una medida de este calado, y por otro, las reticencias que pudiera mostrar parte de la clerecía ${ }^{39}$.

Así, entre las justificaciones expresadas por el Consejo se encontraba-siempre según Pulgar- la necesidad de contar con recursos económicos para emplearlos en una guerra considerada justa, en la que el adversario portugués tenía "aún mucho dinero de lo que truxo de su reyno" así como de lo que "cada día le traen de sus rentas", gracias a lo cual Alfonso V podía afrontar el pago de las soldadas y los gastos que generaba la atracción de fidelidades a partir del otorgamiento de mercedes. En segundo lugar, la toma decretada permitiría allegar de forma rápida un buen número de recursos económicos que, una vez finalizada la causa impositionis -es decir, la guerra-, serían reingresados y mejorados siguiendo el espíritu de las leyes incluidas en los ordenamientos de Cortes relativas a las tomas de plata ${ }^{40}$. De hecho, el primer testamento de Fernando el Católico, dictado poco antes de la batalla de Toro de marzo de 1476, incluiría el firme compromiso de acometer la devolución de todas las cantidades prestadas por los súbditos, entre las cuales se incluía la plata tomada a las iglesias "para la expedición y execuçión desta dicha defensa"41. Tercero, la medida aprobada no suponía una innovación en los procedimientos de financiación extraordinaria, pues existían precedentes tanto en Castilla como en otros territorios, al tiempo que se aseguraba su aceptación entre el clero en función del "serviçio de Dios y vuestro y bien destos reynos" que implicaba. Finalmente, se añadía todo un conjunto de justificaciones de orden político-religioso que trataban de legitimar la medida acordada recurriendo a una interpretación interesada de las Sagradas Escrituras según la cual...

37 BNE, Mss. 1104, ff. 62-63. Cit. AZCONA, T. DE: op. cit., p. 301.

${ }_{38}$ AGS, RGS, julio de 1476, f. 518.

39 PUlGaR, F. DEL: Crónica de los Reyes Católicos, J.M. Carriazo (ed.), Madrid, Espasa-Calpe, 1943, Vol. I, Cap. XLV, pp. 143-145.

40 " $[. .$.$] avemos pensado algunas partes donde se puede aver, pero de ninguna veemos más presta$ que tomar la plata de las iglesias".

${ }^{41}$ CARRASCO MANCHADO, A.I.: op. cit., p. 249. 
“[...] para las neçesidades que ocurrían en Jerusalén, no solamente se tomaua el tesoro del tenplo, mas tomauan los ornamentos e las limosnas que se ofreçían para la fábrica, e para las otras cosas pías, para remediar a las neçesidades que ocurrían en la tierra" $"$.

Con ello quedaba establecido un claro paralelismo entre esta circunstancia bíblica y las contribuciones exigidas por el partido isabelino destinadas a garantizar el triunfo de una causa amparada por la divinidad que había alcanzado de facto la consideración de "guerra santa", triunfo que redundaría a la postre en provecho de los propios bienes eclesiásticos pues "aquel remedio tanbién es remedio al tenplo e a las cosas dél, para que no padezcan los males e destruyçiones que de las guerras geles siguen”.

La exposición de motivos presente en las misivas enviadas a las diferentes diócesis para solicitar el empréstito refiere argumentos muy similares que, además de apelar al "amor, buena voluntad" y lealtad que cabía exigir de los súbditos eclesiásticos naturales del Reino, añaden otros elementos destinados nuevamente a facilitar la aceptación de la medida ${ }^{43}$. Por ejemplo, las cartas enviadas a las autoridades eclesiásticas de los obispados de Plasencia y Coria el 5 de julio de 1476 informando del nombramiento del licenciado Juan de la Rúa como receptor del empréstito, similares en su contenido a la enviada al obispado de Córdoba el 16 de junio del mismo año para dar poder al licenciado Pedro Sánchez de Hinestrosa con el mismo fin ${ }^{44}$, inciden en aspectos como el propio origen eclesiástico de la idea, aconsejada por el Cardenal Pedro González de Mendoza y "otras muchas y devotas religiosas personas" del reino, y respaldada por la alta nobleza (los "grandes") y los miembros del Consejo Real. No obstante, era necesario incorporar argumentos propagandísticos orientados a reafirmar la necesidad de la medida, apelando, por un lado, a la consideración tiránica de la intervención portuguesa en el reino con objeto de poner "grandes escándalos y discordias", y por otro, destacando el caso de extrema necesidad en que se hallaban las arcas regias, toda vez que los restos del tesoro almacenado en el alcázar de Segovia ${ }^{45}$, los préstamos realizados por los súbditos y el fruto de las rentas ordinarias no bastaban para financiar una guerra justa destinada, según el discurso isabelino, a "conservar la libertad d'estos dichos nuestros regnos que non sean puestos e sojudgados por la mano y poder de la gente portoguesa, tanto odiosa y enemiga a la naçión castellana"46. Finalmente, y a fin de resaltar la aceptación que ya había tenido la toma

42 “[...] aún se lee en la Sacra Escritura, que para las neçesidades que ocurrían en Jerusalén, no solamente se tomaua el tesoro del tenplo, mas tomauan los ornamentos e las limosnas que se ofreçían para la fábrica, e para las otras cosas pías, para remediar a las neçesidades que ocurrían en la tierra".

43 La importancia de los discursos políticos legitimadores incluidos en las cartas en las cuales se solicitaban los empréstitos ha sido puesta de relieve por CARRASCO MANCHADO, A.I.: op. cit., pp. 203-204.

44 SANZ SANCHO, I.: op. cit., p. 1183.

45 Entre mayo y junio de 1475 se tomaron 4.560 marcos de plata, de cuya acuñación se pudieron obtener unos 9.000.000 mrs, a los que se añadirían en diciembre del mismo año diversos objetos de oro y plata con los que se pudo acuñar moneda de oro -“castellanos"- por valor de aproximadamente 1.000.000 mrs y moneda de plata -reales- por valor de otro millón. LADERO QUESADA, M.Á. y CANTERA MONTENEGRO, M.: "El tesoro de Enrique IV en el alcázar de Segovia. 1465-75", Historia. Instituciones. Documentos, 31 (2004), pp. 307-351.

46 AGS, RGS, julio de 1476, ff. 517 y 518. 
de plata en otros territorios como forma de generar adhesión a la medida y, por ende a la causa de Isabel ${ }^{47}$, se señalaba la excelente disposición de las personas "que han tenido cargo de la dar" [la plata] a la hora de satisfacer las entregas, todo ello en favor de la "justa defensa" de una opción política cuyo triunfo redundaría tanto en el "bien común" del Reino como en la "honra y libertad, asy de las iglesias como de las personas eclesiásticas y seglares d'ellas".

\subsection{DATOS RELATIVOS AL IMPORTE PAGADO Y SU DESTINO EFECTIVO}

A pesar de la importancia cuantitativa que debió alcanzar el empréstito eclesiástico de 1475-1476 la documentación relativa al total recaudado en cada diócesis y su destino específico es escasa y dispersa, lo cual no constituye un argumento para dudar del carácter general y organizado de la exacción que le atribuyen acertadamente autores como T. de Azcona ${ }^{48}$. En este sentido, los trabajos pioneros sobre el tema del mismo Azcona o I. Sanz parten del análisis de las relaciones de rentas y bienes tomados en circunscripciones eclesiásticas como los obispados de Córdoba ${ }^{49}$ o Zamora ${ }^{50}$ o de documentación relacionada con la devolución de las cantidades prestadas, por ejemplo para la misma diócesis de Córdoba o la de Jaén ${ }^{51}$. No obstante, la inmensa mayoría de las cuentas rendidas por los receptores nombrados para recaudar el empréstito no han llegado hasta nosotros -o no han podido ser localizadas-, por lo que resulta imposible valorar de forma global el grado de cumplimiento del compromiso adquirido por los reyes de destinar el importe obtenido de forma exclusiva a la financiación de la guerra contra Alfonso $\mathrm{V}^{52}$.

El siguiente cuadro recoge de forma sintética información sobre el empréstito en las doce circunscripciones eclesiásticas para la cuales contamos con alguna mención o dato relativo a su cobro: mientras para los obispados de Zamora, Jaén, Córdoba, Ávila y Sigüenza o el cabildo de Burgos conocemos los ingresos globales y el nombre de los agentes encargados de la recaudación -todos ellos de la máxima confianza de los reyes-, en otras circunscripciones (obispados de Calahorra, Palencia, Plasencia y Coria, arzobispado de Sevilla y provincia de Guipúzcoa) tan solo contamos, en el mejor de los casos, con datos relativos a los receptores.

47 “[...] confiando de vosotros que con todo amor y buena voluntad querréys tomar parte d'este cuidado como buenos y leales naturales acordé de vos requeryr con entera confiança”. Ibídem.

48 AZCONA, T. DE: op. cit., pp. 303-304.

49 SANZ SANCHO, I.: op. cit., pp. 1186-1193.

50 AGS, CCA, Diversos, leg. 5, f. 67. Ed. AZCONA, T. DE: op. cit., p. 302.

51 SANZ SANCHO, I.: op. cit.

52 El 15 de enero de 1477 los reyes diputaban a Juan de Sepúlveda, asistente real en la provincia de Guipúzcoa, para que tomase las cuentas de la mitad de la plata prestada por las iglesias de cuya recaudación se habían encargado el provincial fray Francisco de Mondragón y al vasallo de los reyes Antón de Baena. RECALDE RODRÍGUEZ, A. y ORELLA UNZÚE, J.L.: Documentación Real a la Provincia de Guipúzcoa. Siglo XV, San Sebastián, Eusko Ikaskuntza, 1988, Vol. I, doc. 74, pp 180-183. 


\begin{tabular}{|c|c|c|}
\hline CIRCUNSCRIPCIÓN/ INSTITUCIÓN & IMPORTE ABONADO & RECEPTOR/ES \\
\hline Ávila, obispado ${ }^{53}$ & $\begin{array}{l}438.550 \text { mrs y } 554 \text { marcos de plata, } 3 \text { onzas } \\
\text { y } 4 \text { reales }\end{array}$ & $\begin{array}{l}\text { Alfonso Manuel. Doctor, } \\
\text { miembro del Consejo Real }\end{array}$ \\
\hline $\begin{array}{l}\text { Burgos, cabildo }{ }^{54} \text { (también se } \\
\text { cobró en el resto del obispado) }\end{array}$ & $\begin{array}{l}500.000 \mathrm{mrs} \text { ( } 400.000 \mathrm{mrs} \text { en ornamentos y } \\
100.000 \mathrm{mrs} \text { en dinero) }\end{array}$ & $\begin{array}{l}\text { Capellán mayor del rey } \\
\text { Doctor de Alcocer }\end{array}$ \\
\hline \multicolumn{3}{|l|}{ Calahorra, obispado ${ }^{55}$} \\
\hline Córdoba, obispado ${ }^{56}$ & & $\begin{array}{l}\text { Pedro Sánchez de Hinestrosa. } \\
\text { Miembro del Consejo Real }\end{array}$ \\
\hline Coria, obispado ${ }^{57}$ & & Juan de la Rúa \\
\hline Guipúzcoa, provincia ${ }^{58}$ & & $\begin{array}{l}\text { Fray Francisco de Mondragón. } \\
\text { Provincial de la orden de Santa } \\
\text { María de la Merced }{ }^{59} \text {. Antón } \\
\text { de Baena. Vasallo de los reyes }\end{array}$ \\
\hline $\begin{array}{l}\text { Jaén, obispado (iglesias } \\
\text { seculares) }\end{array}$ & $500.000 \mathrm{mrs}$ & $\begin{array}{l}\text { Diego de Ribamartín. Criado } \\
\text { y contino de los reyes }\end{array}$ \\
\hline \multicolumn{3}{|l|}{ Palencia, obispado ${ }^{60}$} \\
\hline Plasencia, obispado $^{61}$ & & Juan de la Rúa \\
\hline $\begin{array}{l}\text { San Bartolomé de Lupiana, } \\
\text { monasterio }^{62}\end{array}$ & 21 marcos de plata & \\
\hline ¿Sevilla, arzobispado? ${ }^{63}$ & & $\begin{array}{l}\text { ¿Alfonso de Velasco. Regidor } \\
\text { de Sevilla? }\end{array}$ \\
\hline Sigüenza, obispado ${ }^{64}$ & $\begin{array}{l}1.006 .196,5 \mathrm{mrs}(261.587,5 \mathrm{mrs} \text { en plata y } \\
\text { oro y } 744.610 \mathrm{mrs} \text { en dinero })\end{array}$ & Gómez de Córdoba \\
\hline $\begin{array}{l}\text { Zamora, obispado (iglesias } \\
\text { seculares) }\end{array}$ & $\begin{array}{l}1.306 .166 \mathrm{mrs} \text { ( } 452 \text { marcos de plata tasados a } \\
2.000 \mathrm{mrs} \text { el marco y } 402.166 \text { de la "fechura" } \\
\text { y oro con } 250.000 \mathrm{mrs} \text { recibidos por el } \\
\text { tesorero Francisco Núñez) }\end{array}$ & $\begin{array}{l}\text { Doctor Nuño Ramírez de } \\
\text { Zamora. Miembro del Consejo } \\
\text { Real y alcalde de casa y corte }\end{array}$ \\
\hline
\end{tabular}

${ }^{53}$ AGS, EMR, leg. 43, f. 73 . AGS, RGS, noviembre de 1475, f. 714

${ }^{54}$ Archivo Histórico de la Catedral de Burgos, RR-20, ff. 31v-35.

${ }^{55}$ Se sabe de la recaudación del empréstito a través de un documento dado en 1500 , aunque se desconocen los datos relativos al monto total percibido y al agente encargado de la recepta. AZCONA, T. DE: op. cit., p. 303.

${ }^{56}$ SANZ SANCHO, I.: op. cit., p. 1183.

${ }^{57}$ AGS, RGS, julio de 1476, f. 518.

${ }^{58}$ RECALDE RODRÍGUEZ, A. y ORELLA UNZÚE, J.L.: op. cit., Vol. I, doc. 74, pp 180-183.

${ }^{59}$ AGS, RGS, febrero de 1475, f. 160.

${ }^{60}$ CARRASCO MANCHADO, A.I.: op. cit., p. 160.

${ }^{61}$ AGS, RGS, julio de 1476, f. 518.

${ }^{62}$ SIGÜENZA, J. DE: Historia de la orden de San Jerónimo, Madrid, Bailly Baillière eHijos, 1909 (2a ed.), Vol. II, p. 13.

${ }^{63}$ LADERO QUESADA, M.Á.: "Dos viajes de Isabel la Católica (Sevilla, 1477. Baza, 1489)", Iacobus: revista de estudios jacobeos y medievales, 13-14 (2002), pp. 235-236.

${ }^{64}$ AGS, EMR, leg. 36, f. 130.

${ }^{65}$ AGS, CCA, Diversos, leg. 5, f. 67. 
Los datos procedentes de las cuentas rendidas por los receptores de Ávila y Sigüenza -las únicas que han podido ser localizadas entre los fondos simanquinos- permiten realizar algunos comentarios sobre el destino de los fondos recaudados que, en su mayoría, parece responder a la devolución de los adelantos realizados por nobles y prelados, el pago de los servicios militares prestados por estos, y la financiación de la tesorería de Fernán Núñez. De los 554 marcos de plata, 3 onzas y 14 reales recaudados por el doctor Alonso Manuel a partir de noviembre de 1475 en las iglesias del obispado de Ávila ${ }^{66}$-que pudieron alcanzar un valor aproximado de $1.036 .000 \mathrm{mrs}$ contabilizando el marco de plata a $1.870 \mathrm{mrs}^{67}-, 181$ marcos, dos onzas y siete reales fueron librados al titular de la diócesis, Alfonso de Fonseca, que había servido con sus huestes a los reyes en episodios militares tan decisivos como la toma de Alcaraz en mayo de 1475, la batalla de Toro (uno de marzo de 1476) -donde actuó como capitán de una de las escuadras del ejército isabelino-, el cerco y asalto de la misma ciudad en septiembre de 1476 o la posterior toma de Cantalapiedra ${ }^{68}$. Por otra parte, los 373,5 marcos y una onza restantes de la cantidad total percibida en plata acabaron engrosando el cargo del tesorero Fernán Núñez, presumiblemente en satisfacción de otros gastos militares, mientras que de los $438.550 \mathrm{mrs}$ entregados "en dineros" -quizás correspondientes a la mitad de las rentas de fábrica de las iglesias-, la mayor parte (352.320 mrs) terminó en manos del mismo obispo de Ávila, siendo muy escasa la cantidad percibida por Fernán Núñez $(85.000 \mathrm{mrs})$. A estas partidas habría que añadir $53.475 \mathrm{mrs}$ gastados por el receptor en cobrar el empréstito en la catedral abulense y en seis de los arciprestazgos de la diócesis, a los cuales se sumarían otros $47.550 \mathrm{mrs}$ desembolsados para llevar a cabo la colecta de 373 marcos de plata, una onza, siete reales y $146.278 \mathrm{mrs}$ de los arciprestazgos de Arévalo y Olmedo, y para transportar las cantidades recaudadas de Madrigal a Olmedo, y de allí a Valladolid donde fueron entregadas a Fernán Núñez en fecha desconocida ${ }^{69}$.

En Sigüenza el destino de los fondos fue bastante similar. Los 1.006.196,5 mrs recaudados por Gómez de Córdoba en las iglesias del obispado fueron distribuidos entre el tesorero de la reina Fernán Núñez - que percibiría a través de Juan de Hervás 223.094 mrs-, y el Cardenal Mendoza, titular de la diócesis y beneficiario de 700.000 mrs librados para el pago de un millón de mrs que debía recibir, quizás como devolución de alguno de los préstamos realizados a los reyes para financiar la contienda ${ }^{70}$ o en pago a los servicios militares prestados por sus huestes ${ }^{71}$. Los restantes asientos

${ }^{66}$ Carta de los reyes dada en Dueñas 17 de noviembre de 1475 nombrándole receptor en AGS, RGS, noviembre de 1475 , f. 714 .

${ }^{67}$ Este fue el precio tasado en la toma de Sigüenza. AGS, EMR, leg. 36, f. 130.

68 PULGAR, F. DEL: Crónica de los Reyes Católicos..., Vol. I, pp. 119, 208, 266, 281-283 y 294.

${ }^{69}$ AGS, EMR, leg. 43, f. 73.

${ }^{70}$ Por ejemplo, en un apuntamiento de las libranzas proyectadas con cargo a las alcabalas y tercias de los señoríos del arzobispado de Toledo de los años 1477-1479 consta un asiento referido al pago $500.000 \mathrm{mrs}$ al Cardenal de España mandados librar por la reina en cuenta de los $700.000 \mathrm{mrs}$ del "socorro" anticipado por los recaudadores del partido "porque los ha de aver el dicho cardenal que los prestó sobre braçalete de la reyna". AGS, EMR, leg. 23, f. 155.

${ }^{71}$ Las intervenciones militares del Cardenal Mendoza en VILLALBA RUIZ DE TOLEDO, F.J.: El cardenal Mendoza ante la guerra civil castellana (1474-1482), Madrid, Universidad Autónoma, 1983; El Cardenal Mendoza (1428-1495), Madrid, Rialp, 1988, pp. 60-61. 
de la cuenta se refieren -igual que en la diócesis de Ávila-, a gastos de carácter logístico y comprenden, por un lado, los 72.000 mrs cobrados por el receptor Gómez de Córdoba en concepto de salario por el año que estuvo ocupado en la recaudación del empréstito -a razón de 200 mrs diarios que incluían la remuneración de un escribano y un platero- y, por otro, $12.260 \mathrm{mrs}$ gastados por el oficial en el envío de cartas y mensajeros por las iglesias del obispado, en el proceso judicial abierto por el arzobispo de Toledo Alonso Carrillo de Acuña del que daremos cuenta más adelante, y en otros conceptos como la compra de un "arca blanca con su llave e çerradura" utilizada para trasladar la plata a la corte $(150 \mathrm{mrs})$ o el pago de los acemileros y ballesteros encargados del transporte desde Sigüenza a Madrid (550 mrs), donde fue entregada en la corte al tesorero Fernán Núñez ${ }^{72}$.

Sin embargo, a pesar de toda la carga legitimadora tendente a vincular el empréstito eclesiástico con la financiación del conflicto sucesorio, una vez recuperada la obediencia de la mayor parte de los territorios del Reino -algo que se conseguiría a lo largo del verano de 1477, cuando se tomó Trujillo y se completó la sumisión de otras áreas de la baja Extremadura-, parte de los fondos percibidos pasaría a ser invertida en gastos, como los generados por ceremonias de representación propagandística de la realeza, que poco o nada tenían que ver con los fines expresados inicialmente para justificar la exacción. Este sería el destino, por ejemplo, de $250.000 \mathrm{mrs}$ de la "plata de las iglesias" custodiada por el regidor sevillano Alfonso de Velasco empleados en sufragar parte del coste ocasionado por la entrada realizada por Isabel en Sevilla el 24 de julio de 1477 con objeto de tomar el poder efectivo en la ciudad y establecer la paz en la Baja Andalucía, lo cual suponía un $35 \%$ del total ingresado por el doctor Antón Rodríguez de Lillo (713.300 mrs) para pagar los gastos suntuarios del séquito regio ${ }^{73}$. Por lo demás, esta última mención tiene interés pues permite ampliar la recaudación del empréstito a circunscripciones como el arzobispado de Sevilla para las cuales no se contaba con datos concretos ${ }^{74}$.

${ }^{72}$ El cargo y la data general en AGS, EMR, leg. 36, f. 130. El detalle por conceptos de los 12.260 mrs en la cuenta dada por Gómez de Córdoba en Madrid el 8 de febrero de 1477. AGS, EMR, leg. 39, f. 128. Además del arca se compraron "lías" o cuerdas para atarla por $10 \mathrm{mrs}$. Asimismo, el pago del transporte se realizó de la siguiente forma: el acemilero que llevó la plata desde Sigüenza a Atienza recibió dos reales (60 mrs), mientras que los cuatro ballesteros que conformaban su escolta percibieron 100 mrs; el camino entre Atienza y Madrid, en el cual se emplearon seis días "en yda e venida", fue realizado por otro acemilero que cobró $150 \mathrm{mrs}$, acompañado de tres ballesteros a los cuales Gómez de Córdoba solo pagó el salario de cuatro días ( $240 \mathrm{mrs}$, o $20 \mathrm{mrs}$ por día y ballestero).

73 LADERO QUESADA, M.Á.: "Dos viajes...", pp. 234-241.

${ }^{74}$ De hecho, T. de Azcona supone basándose en esta ausencia de documentación que los arzobispados de Sevilla y Santiago no contribuyeron. AZCONA, T. DE: op. cit., p. 304. 
Tabla 1. Cuenta de la plata y dineros que se cobraron en la iglesia mayor de Ávila y de seis arciprestazgos, junto a los arciprestazgos de Arévalo y Olmedo, y la villa de Madrigal $^{75}$

\begin{tabular}{|l|r|r|r|}
\hline \multicolumn{3}{|c|}{ CARGO DE LA PLATA } \\
\hline \multicolumn{1}{|c|}{ Procedencia } & \multicolumn{1}{|c|}{ Marcos } & Onzas & Reales \\
\hline $\begin{array}{l}\text { Iglesia mayor de Ávila y todas las iglesias de seis arciprestazgos sin los } \\
\text { arciprestazgos de Arévalo y Olmedo, sin Madrigal }\end{array}$ & 181 & 2 & 7 \\
\hline Iglesias de Olmedo y su arciprestazgo & 207 & 1 & 7 \\
\hline Iglesias del arciprestazgo de Arévalo & 136 & - & - \\
\hline Iglesia de Madrigal & 30 & - & - \\
\hline TOTAL & $\mathbf{5 5 4}$ & $\mathbf{3}$ & $\mathbf{1 4}$ \\
\hline
\end{tabular}

\section{DATA DE LA PLATA}

Obispo de Ávila, por mandamiento de la reina, 181 marcos, dos onzas y 7 reales de plata

Tesorero Fernán Núñez, en tres veces, por mandamientos de la reina nuestra señora 73 marcos y medio, 1 onza de plata

TOTAL

\section{CARGO DEL DINERO}

Mrs que dio la iglesia mayor de Ávila y las otras iglesias de seis arciprestazgos

Mrs que dieron las iglesias de Olmedo y su arciprestazgos

Mrs que dieron las iglesias del arciprestazgo de Arévalo

TOTAL $^{76}$

405.272

8.000

24.278

438.550

75 AGS, EMR, leg. 43, f. 73.

${ }^{76} \mathrm{El}$ total es erróneo. Son $437.550 \mathrm{mrs}$. 


\begin{tabular}{|l|r|}
\hline \multicolumn{2}{|c|}{ DATA DEL DINERO } \\
\hline Obispo de Ávila por virtud de un mandamiento de la reina & 352.320 \\
\hline $\begin{array}{l}\text { Gasto en cobrar la dicha plata y dineros de la iglesia mayor y de las iglesias de los seis } \\
\text { arciprestazgos según está asentado en los libros "e asy mismo está en la obligaçión que se fizo } \\
\text { al deán e cabildo e a las dichas iglesias de los dichos seys arçiprestadgos" }\end{array}$ & 53.475 \\
\hline Al tesorero Fernán Núñez, por dos cédulas de la reina & 85.000 \\
\hline $\begin{array}{l}\text { Gastos que se hicieron en cobrar los 373 marcos, 1 onza y 7 reales de plata de los arciprestazgos } \\
\text { de Arévalo y Olmedo, y 146.278 mrs, y de la gente que fue menester para traerlo a Madrigal, } \\
\text { y de Madrigal a Olmedo y de Olmedo a Valladolid donde se entregó al tesorero Fernán Núñez } \\
\text { por mandado de la reina, y de los derechos de la receptoría }\end{array}$ & 47.550 \\
\hline TOTAL GASTADO POR EL DOCTOR & $\mathbf{5 3 8 . 3 4 5}$ \\
\hline
\end{tabular}

Tabla 2. Cuenta en mrs de la plata recibida en el obispado de Sigüenza por el receptor Gómez de Córdoba en el empréstito de $1476^{78}$

\begin{tabular}{|l|r|}
\hline \multicolumn{2}{|c|}{ CARGO } \\
\hline $\begin{array}{l}\text { Plata, con el oro que en ella estaba, que fue tasado en } 2.452 \mathrm{mrs} \text {, y el dinero de las iglesias de } \\
\text { Sigüenza, tal y como consta por la obligación y cartas de pago que en nombre de los dichos } \\
\text { reyes Gómez de Córdoba hizo y dio de lo susodicho a las dichas iglesias }\end{array}$ & $1.006 .196,5$ \\
\hline \multicolumn{2}{|c|}{ Desglose por conceptos } \\
\hline $\begin{array}{l}147 \text { marcos y una onza y medio real de plata, de los cuales quedaron, descontando de ello } \\
\text { mermas, soldaduras y menoscabos de ley "a vista" y sobre juramento del platero según parece } \\
\text { por los libros del recibo, 139 marcos y dos onzas y cuatro reales y medio de plata mercadera. } \\
\text { A 1.870 mrs el marco "a como el dicho Gómez de Córdoba reçibió por mandado del cardenal", } \\
\text { ascienden en total a 259.135,5 mrs, a los cuales se añaden 2.452 mrs más en que fue tasado el } \\
\text { oro que en la dicha plata estaba "a vista" del dicho platero }\end{array}$ \\
\hline Dinero & $261.587,5$ \\
\hline
\end{tabular}

${ }^{77}$ Se trata del doctor Alfonso Manuel, nombrado receptor de la plata del obispado de Ávila el 7 de noviembre de 1475. AGS, RGS, noviembre de 1475, f. 714. Cit. NIETO SORIA, J.M.: Iglesia y génesis..., p. 341.

${ }^{78}$ AGS, EMR, leg. 36, f. 130. 


\begin{tabular}{|c|c|}
\hline \multicolumn{2}{|l|}{ DATA } \\
\hline $\begin{array}{l}\text { Dio y pagó al cardenal para en cuenta de un cuento de mrs que en él le fue librado } 700.000 \text {, } \\
661.470 \text { mrs en dineros y } 38.530 \text { mrs en } 21 \text { marcos y } 4 \text { onzas de plata que quedaron, quito de } \\
\text { ello mermas y soldaduras, en } 20 \text { marcos, } 5 \text { onzas y } 5 \text { reales y medio de plata, en que no hubo } \\
\text { oro ninguno }\end{array}$ & 700.000 \\
\hline $\begin{array}{l}\text { Dio a Fernán Núñez, tesorero de la reina, y por él a Juan de Hervás, } 125 \text { marcos, } 7 \\
\text { onzas y } 6 \text { reales de plata sin descontar mermas ni soldaduras y menoscabos de ley, que } \\
\text { descontado de la plata según que el platero "so cargo de juramento" mandó descontar, } \\
\text { quedaron en } 118 \text { marcos y } 5 \text { onzas de plata mercadera, que a } 1.870 \text { mrs el marco son } \\
220.642,5 \mathrm{mrs} \text {, a los que se han de cargar } 2.452 \mathrm{mrs} \text { en que fue tasado el oro de esta plata }\end{array}$ & 223.094 \\
\hline $\begin{array}{l}\text { Salario de Gómez de Córdoba, que estuvo un año entendiendo en la recaudación de la dicha } \\
\text { plata, a razón de } 200 \text { mrs cada día que la reina le mandó dar de salario para él, un escribano y } \\
\text { un platero }\end{array}$ & 72.000 \\
\hline $\begin{array}{l}\text { Gastos relacionados con la recaudación (envío de cartas y mensajeros por cada una de las } \\
\text { iglesias del obispado), así como en el pleito de Alcalá que sobre ello se trató con el arzobispo } \\
\text { de Toledo "porque enbiava mandar a las dichas iglesias que non pagasen cosa ninguna e a los } \\
\text { juezes que no diesen cartas ningunas contra las iglesias y los ynivía", en llevar la plata que se } \\
\text { dio al tesorero a la corte a Madrid, y en otras cosas a ello tocantes como más largamente se } \\
\text { contiene en la copia y relación que Gómez Fernández [sic] dio }\end{array}$ & 12.260 \\
\hline TOTAL & 1.007 .354 \\
\hline ALCANCE & 1.157 \\
\hline
\end{tabular}

\subsection{LAS RESISTENCIAS A LA EXACCIÓN: LOS CASOS DE BURGOS Y SIGÜENZA}

A pesar de todo el aparato ideológico expresado, y del respaldo que el empréstito recibió por parte de eclesiásticos tan influyentes como fray Hernando de Talavera o Pedro González de Mendoza, su éxito requería del consenso y la colaboración, diócesis por diócesis, del conjunto del estamento eclesiástico. El propio cronista Hernando del Pulgar, siguiendo el mismo espíritu expresado en las cartas enviadas a los obispados de Coria o Plasencia en 1476, exageraba intencionadamente los apoyos que recibió la toma de la plata al señalar cómo "toda la clerecía, considerada la neçesidad de la guerra, de su voluntad dieron la mitad de la plata que avía en cada vna iglesia"79.

En efecto, hubo instituciones y prelados especialmente cercanos a los reyes que prestaron su colaboración efectiva en las tareas de cobro. Así, el obispo de Palencia Diego Hurtado de Mendoza, sobrino del Cardenal de España, conseguía en septiembre de 1475 - estando Isabel en la ciudad ${ }^{80}$ - que las iglesias y monasterios de su obispado prestasen a los reyes 80 marcos, dos onzas y cuatro reales de plata, e incluso se

79 PULGAR, F. DEL: Crónica de los Reyes Católicos..., Vol. I, p. 145.

${ }^{80}$ Isabel estuvo en Palencia desde al menos el 19 de septiembre hasta el fin del mes. RUMEU DE ARMAS, A.: Itinerario de los Reyes Católicos (1474-1516), Madrid, CSIC-Instituto Jerónimo Zurita, 1974, pp. 46-47. 
ofrecía a recorrer la diócesis para recaudar el empréstito ${ }^{81}$. Por su parte, según fray José de Sigüenza, que escribe más de un siglo después del empréstito incorporando en su obra una visión claramente apologética del mismo ${ }^{82}$, la orden jerónima habría ofrecido de buen grado a los reyes "essa poca plata que tenian", entre la cual se encontraban 21 marcos de plata procedentes del monasterio de San Bartolomé de Lupiana "que parecia podia prestarse, por no hazer precisa falta a la casa". Llegado este punto, hay que señalar cómo el arzobispo Carrillo también había solicitado, al parecer, la entrega de la plata de Lupiana -cenobio con el cual habían mantenido una estrecha relación- negada a la postre por el general fray Juan de Ortega en razón de la obediencia prestada por la orden a Isabel y de su sospecha de que la misma petición recaería posteriormente sobre el resto de monasterios jerónimos del arzobispado de Toledo ${ }^{83}$. Igualmente, en los obispados de Córdoba o Jaén sus respectivos prelados y cabildos acataron el mandato, sin que la documentación explicite episodios conflictivos en torno a la recaudación ${ }^{84}$ más allá del intento por moderar la contribución llevado a cabo por los delegados eclesiásticos de Córdoba a partir de una exposición de causas tendente a recalcar la dificil situación económica de la diócesis. Así, entre los motivos alegados se encontraba cierta incursión realizada por los granadinos en tierras del obispado, la existencia de otras contribuciones -subsidios y jubileos- autorizadas por el papado, las discordias entre nobles y su impacto negativo en la percepción de los diezmos, o la bajada del precio del marco de plata hasta los $1.800 \mathrm{mrs}$ como consecuencia de la mala cosecha de $1476^{85}$.

No obstante, hubo territorios en los cuales existe plena constancia de la resistencia activa a la exacción ejercida por parte del clero, lo cual desmiente la colaboración total del estamento eclesiástico referida por la propaganda isabelina. En Burgos, cuyo obispo Luis de Acuña era un destacado partidario de la opción portuguesa, el cabildo catedralicio se resistió inicialmente a la entrega de ciertos ornamentos, solicitada por Fernando el Católico el 19 de agosto de 1475 cuando se encontraba en la ciudad con objeto de dirigir el asalto a su castillo, alegando la necesidad de contar con la aprobación del prelado. Por el contrario, los canónigos aceptaban conceder al rey $100.000 \mathrm{mrs}$ procedentes de la mesa capitular, aunque tomados inicialmente del dinero recaudado para el subsidio pontificio ${ }^{86}$. La resistencia se manifestó de forma

${ }^{81}$ CARRASCO MANCHADO, A.I.: op. cit., p. 160.

82 El Padre Sigüenza señala cómo "los reyes pidieron a las yglesias les ayudassen con lo que pudiessen, dando sus Reales palabras que lo boluerian en sosegando tan grandes rebueltas. Acudieron todos con voluntad y animo largo a su deseo y seruicio, y ansi se haria siempre si se viessen las cosas tan bien empleadas, ni dudariamos de dar los calizes y cruzes, como no la viesemos malograr en las vñas de tan hambrientas harpias". SIGÜENZA, J. DE: op. cit., Vol. II, p. 13.

${ }_{83}$ Ibidem, pp. 13-14. Para informar a Carrillo se diputaría a dos religiosos que acudirían con una instrucción en la cual se justificaba profusamente la aceptación del empréstito solicitado por los reyes.

${ }^{84}$ Pedro de Solier, obispo de Córdoba, acataba el empréstito solicitado el 31 de julio de 1476, al igual que hacía el cabildo cordobés el 2 de agosto. SANZ SANCHO, I.: op. cit., p. 1184.

${ }^{85}$ Ibídem, pp. 1184-1185.

${ }^{86}$ Lo relativo a este episodio en SERRANO, L.: Los Reyes Católicos y la ciudad de Burgos, Madrid, CSIC, 1942, pp. 149-151. El cabildo burgalés daría poder el mismo día 19 de agosto a García Ruiz de la Mota, tesorero, a Iñigo de Mendoza, arcediano de Huete, y a Diego Sánchez, para que determinasen la manera de pagar a la Corona estos 100.000 mrs. Archivo Histórico de la Catedral de Burgos, RR-20, ff. 31v-32. Posteriormente encomendaba a Diego Sánchez determinar cómo hacer el pago de esta cantidad. 
mucho más evidente el 22 de agosto cuando Fernando ordenaba convocar de nuevo al cabildo para exigir la entrega inmediata de las llaves del "sagrario" de la catedral, de las cuales se harían cargo posteriormente su capellán mayor y el doctor de Alcocer, encargados de examinar las reliquias y el tesoro allí depositado, y de tomar ciertas piezas de plata y oro que alcanzaron un valor total de $400.000 \mathrm{mrs}^{87}$. Frente a esta actitud, meses después -el 3 de febrero de 1476-, la reina trataba de contemporizar con objeto de crear unas condiciones mínimas de consenso en torno a la usurpación realizada seis meses antes. Para ello reiteraba, por "fe e palabra real" dada a Luis de Velasco, miembro del Consejo Real encargado de negociar los aspectos relativos al empréstito de la plata de Burgos con el obispo Luis de Acuña, su promesa de restituir las cantidades tomadas de iglesias, monasterios y abadías en el primer "pedido y monedas" otorgado por las Cortes "en los logares çiertos e mejor parados donde vos la pidiéredes e nonbráredes, de tal forma que a vos sea pagado e acudido con toda la dicha plata e mrs". Incluso, Isabel ofrecería la posibilidad de devolver el préstamo con cargo a las alcabalas, tercias, pechos y derechos de cualquier partido del Reino a fin de facilitar con ello la articulación de un marco de confianza en relación con la política regia ${ }^{88}$.

El contenido de esta carta anticipa la fórmula de reembolso de las cantidades prestadas adoptada en las Cortes celebradas en Madrigal a lo largo del mes de abril del mismo año 1476 tras la victoria de Peleagonzalo, en cuyo transcurso los procuradores aprobarían un servicio extraordinario de 132 millones de mrs destinado al pago del sueldo de "muchos perlados e caualleros e escuderos que nos han seruido en esta guerra" completados con una partida extra de 30 millones de mrs a cobrar en dos pagas durante 1477 -negociada por el Cardenal de España, el duque del Infantado, el duque de Alba y otros "grandes" del Consejo Real ${ }^{89}$-, y destinada a la devolución de la plata, pan y dineros entregados por el episcopado, iglesias y monasterios del Reino pues, a juicio de los reyes, la cantidad inicial otorgada se consideraba insuficiente para incluir estos pagos sin comprometer la devolución del resto de adelantos destinados "a pagar el sueldo a la gente que avemos de tener" ${ }^{\prime \prime}$.

Ibídem, f. 33v. El 22 de septiembre el cabildo alcanzaba el acuerdo de entregar los 100.000 mrs. Ibídem, ff. 34-35. Finalmente, el 25 del mismo mes García Díaz de Sanzoles, prior y receptor del subsidio decretado por Sixto IV para la lucha contra el turco, certificaba la recepción de $60.000 \mathrm{mrs}$ como parte de los 100.000 prestados por el cabildo para entregarlo a Fernando el Católico. Ibídem, f. 35.

${ }^{87}$ Se tomaron una cruz de plata sobredorada, en mal estado, con esmaltes y un peso de 15 marcos; 2 candelabros dorados de 15 y 16 marcos de plata; un cáliz de oro con esmaltes de 4 marcos, una onza y dos ochavos; la patena de este cáliz de plata sobredorada; y otras piezas por valor de 200 marcos de plata. SERRANO, L.: op. cit., pp. 150-151.

${ }^{88}$ AGS, RGS, febrero de 1476, f. 79.

89 CARANDE, R. y CARRIAZO, J.M. (eds.): El Tumbo de los Reyes Católicos del Concejo de Sevilla, Sevilla, Universidad Hispalense, 1968, Vol. I, pp. 153-155.

90 "si este dicho enprestido de pan e plata e marauedis que las dichas yglesias e monesterios han fecho se ouiesen de pagar dellos quedaria muy poca contia para pagar el sueldo a la gente que avemos de tener e asi con esto non se proueeria conplidamente en lo venidero". Ibídem, Vol. I, pp. 153-154. Otras referencias a la restitución de la plata y rentas de fábrica tomadas en las cartas enviadas a los obispados de Coria y Plasencia en julio de 1476. "[...] por la presente os seguro y prometo y doy mi fe y palabra real en nonbre del dicho rey mi señor y mío, y por virtud del poder que de su señorío tengo de mandar pagar a esta dicha iglesia d'esa dicha çibdad y a todas las iglesias y monesterios del dicho obispado y a 
Junto al caso de Burgos, que es necesario valorar en función de la toma de partido de su obispo por la facción portuguesa, la resistencia planteada por el clero de la diócesis de Sigüenza constituye uno de los ejemplos que mejor expresa las dificultades que hubo de afrontar el partido isabelino a la hora de proceder al cobro efectivo del empréstito ordenado, especialmente si tenemos en cuenta las especiales circunstancias políticas de esta sede derivadas de la titularidad episcopal ejercida por Pedro González de Mendoza desde $1467^{91}$ que, a la postre, terminaron por convertirla en escenario de un conflicto que desmiente de nuevo el elevado grado de colaboración prestado por toda la Iglesia castellana referido por la propaganda isabelina. De ello da buena cuenta, en primer lugar, la mención al año entero que tardaría Gómez de Córdoba, receptor del empréstito, en llevar a buen puerto la percepción de las cantidades exigidas ${ }^{92}$, cuyo producto ascendió en total -tal y como ha quedado señalado- a algo más de $1.000 .000 \mathrm{mrs}^{93}$. A esta demora contribuyó, sin duda, la ausencia de una postura unificada en el seno del propio estamento eclesiástico de la diócesis, aprovechada por los prelados que apoyaban a Alfonso V para declarar la ilegalidad e ilegitimidad de la medida fiscal acordada por Isabel.

La cuenta del empréstito dada por el receptor de Sigüenza aporta, en este sentido, información muy valiosa relativa a los intentos de deslegitimación y boicot de la medida, destinados a lograr un doble objetivo: frenar el apoyo eclesiástico a la causa isabelina y limitar sus posibilidades de financiación. La mención en la cuenta general dada por Gómez de Córdoba a los gastos ocasionados por el llamado "pleito de Alcalá" promovido por el arzobispo de Toledo Alonso Carrillo de Acuña, firme detractor de Isabel, y la referencia a cómo el anciano prelado "enbiava mandar a las dichas iglesias que non pagasen cosa ninguna, e a los juezes que no diesen cartas ningunas contra las iglesias" no dejan lugar a dudas sobre el enfrentamiento sostenido entre los dos personajes más relevantes de la clerecía castellana por la cuestión de la toma de la plata en una de las diócesis regidas por el Cardenal Mendoza, enemigo político de Carrillo ${ }^{94}$.

cada una d'ellas realmente y con efecto todo lo que asy me prestáredes con el valor de las fechuras de la dicha plata y oro y mitad de la renta de la fábrica que asy fuere entregada al dicho liçençiado Juan de la Rúa de los treynta cuentos de pedidos y monedas que por los procuradores d'estos mis regnos fueron otorgados al rey mi señor y a mí para pagar la dicha plata y mrs de fábrica que por las dichas iglesias y monesterios d'estos mis regnos nos han seydo prestados, los quales dichos treynta cuentos se an de coger y de recabdar el año venidero de setenta y siete años, que para ello vos mandaré dar mis cartas de libramientos y las otras provisiones que fueren nesçesarias". AGS, RGS, julio de 1476, ff. 517 y 518.

${ }_{91}$ La trayectoria vital y política de Pedro González de Mendoza en VILLALBA RUIZ DE TOLEDO, F.J.: El cardenal Mendoza ante la guerra civil castellana (1474-1482), Madrid, Universidad Autónoma, 1983; El Cardenal Mendoza (1428-1495). VILCHES VIVANCOS, F.: El cardenal Mendoza datos biográficos definitivos y obra literaria, Guadalajara, Institución Provincial de Cultura Marqués de Santillana, 1994.

${ }_{92}$ Para acometer el cobro iría en compañía de un escribano que daba fe de las cantidades recaudadas y de un platero encargado de la tasación de los metales preciosos.

${ }_{93} 261.587,5 \mathrm{mrs}$ procedentes de 139 marcos, dos onzas y cuatro reales y medio de plata "mercadera" (tasada a $1.870 \mathrm{mrs}$ el marco) y $2.452 \mathrm{mrs}$ en que fue tasado el oro que en la dicha plata estaba; y otros 744.610 mrs "en dineros". AGS, EMR, leg. 36, f. 130.

94 El análisis paralelo de ambas figuras y sus trayectorias políticas en NIETO SORIA, J.M.: "Dos prelados en la encrucijada de un trono: Alfonso Carrillo de Acuña y Pedro González de Mendoza", Torre de los Lujanes, 54 (2004), pp. 49-64. 
A estos datos se añaden las referencias incluidas en la cuenta rendida en Madrid el 28 de febrero de 1477 de los mrs gastados por el receptor en el envío de cartas y mensajeros a las iglesias del obispado de Sigüenza para exigir la contribución, a partir de las cuales conocemos con todo lujo de detalles el procedimiento interno llevado a cabo para acometer el cobro del empréstito ${ }^{95}$. Gracias a esta documentación sabemos cómo una vez transmitida la orden regia al clero seguntino, fue convocada una asamblea integrada por los arciprestes o vicarios de cada una de las circunscripciones en que se encontraba dividido el obispado - cada uno acompañado de dos clérigos "de los prinçipales" - con objeto de debatir los aspectos relativos a la toma exigida por los reyes. Previamente, el clero secular de cada arciprestazgo habría de reunirse en asambleas para elegir a los representantes enviados a Sigüenza, en las cuales se pudo acordar la posición que estos debían expresar en la asamblea general del obispado ${ }^{96}$.

Más allá del debate establecido en torno al pago del empréstito, estas asambleas tienen relevancia por cuanto facilitaban la apertura de cauces de participación y de expresión a los miembros del clero secular diocesano en un momento de gran efervescencia política, si es que no fueron directamente utilizadas para establecer un debate en torno a los argumentos que sostenían la legitimidad de la opción isabelina y/o de la toma de plata ordenada. A ello se sumaba la trascendencia que la aceptación del empréstito por los clérigos allí reunidos podía tener como mecanismo de amplificación propagandística, ya que tanto la cooperación activa como el rechazo a la toma podrían servir de base para sancionar una u otra opción política ${ }^{97}$. De esta forma, el hecho de contar con el consenso de un grupo de poder como el eclesiástico facilitaba la difusión de la virtud y necesidad de la causa que legitimaba la imposición y, por lo tanto, podía llegar a generar un efecto multiplicador de la confianza que los fieles podían depositar en cada uno de los partidos en lid a partir de la presión ejercida desde el púlpito.

El resultado de la asamblea general reunida en la catedral de Sigüenza antes del mes de marzo de $1476^{98}$, que contó con la participación de los arciprestes y vicarios de la diócesis junto a otros clérigos y curas, no pudo ser más desalentador para la causa isabelina, habida cuenta de que se trataba teóricamente de un territorio bajo el control del cardenal Mendoza, además de obispo señor de la ciudad de Sigüenza y su tierra. El receptor Gómez de Córdoba se encarga de reflejar en los asientos de su

95 AGS, EMR, leg. 39, f. 128.

96 "Primeramente que costaron levar a Molyna e a las otras iglesias de su açiprestadgo las primeras cartas qu'el prior de la iglesia dio para que todas las iglesias del dicho obispado se juntasen y enbiasen de cada açiprestadgo a la iglesia de Sygüença al arçipreste o vicario con otros dos clérigos de los prinçipales d'él para çierto día a entender en lo del enprestado de la plata, trezientos e çinquenta mrs". En la cuenta se indica cómo se dieron otras cartas semejantes para los arciprestazgos de Ariza, Medinaceli, Berlanga, Caracena, Ayllón, Atienza y Sigüenza. Su precio total ascendió a $2.050 \mathrm{mrs}$. Posteriormente se señala cómo "por virtud d'estas primeras cartas se juntaron en la iglesia de Sygüença los açiprestes [sic] y vicarios d'estos açiprestadgos y otros clérigos y curas de las iglesias d'ellos y apelaron todos juntamente de los mandamientos del señor cardenal". AGS, EMR, leg. 39, f. 128.

97 SANZ SANCHO, I.: op. cit., p. 1196.

98 La fecha ante quem se deduce de la mención relativa a los gastos realizados por el receptor Gómez de Córdoba en ir a Tordesillas -donde Isabel se encontraba en marzo- y a Madrigal, escenario de la reunión de las Cortes a lo largo del mes de abril, con objeto de informar a los reyes. RUMEU DE ARMAS, A.: op. cit., pp. 52-53. 
cuenta el fracaso de las negociaciones y la apelación realizada por el clero "juntamente de los mandamientos del señor cardenal", con el consiguiente trastorno que ello ocasionaría en sus tareas de gestión recaudatoria, pues hubo de trasladarse a Tordesillas y a Madrigal -donde se reunirían las Cortes durante el mes de abril-para informar a los reyes y al Cardenal de España de las dificultades con que había tropezado su empresa. Ante las resistencias planteadas, Pedro González de Mendoza realizaría una "declaraçión" en la que ordenaba el pago de dos doblas de oro por cada marco de plata "de los que se fallasen en todas las iglesias del dicho obispado" mitad del dinero destinado a las fábricas, así como la comparecencia bajo juramento de los curas y clérigos con objeto de determinar "quánto es la plata y fábrica que cada una de las iglesias tenía”. Para ello, Juan López de Medina, arcediano de Almazán, provisor del obispado de Sigüenza, miembro del Consejo Real y una de las personas de confianza del Cardenal de España ${ }^{100}$, hubo de enviar nuevas cartas instando a los curas y mayordomos de las iglesias a acudir a la catedral seguntina con una declaración de estas cantidades "e para ver lo qu'el dicho señor cardenal avía mandado sobre la apelaçión por ellos en este caso fecha de los mandamientos de su señoría" ${ }^{101}$. Se trata del mismo procedimiento de organización del cobro seguido en la diócesis de Córdoba ${ }^{102}$, y plasmado en las mencionadas cartas enviadas a los obispados de Plasencia y Coria en julio de 1476, en las cuales se ordenaba a los arciprestes, vicarios, mayordomos y curas declarar igualmente bajo juramento el valor de estos conceptos, y su entrega en la catedral en manos de un beneficiado del cabildo -nombrado por la institución capitular y el obispo- que, además, se encargaría de cotejar el valor de las remesas recibidas con la información económica contenida en los libros de visita de las iglesias, "porque en ello non aya encubierta alguna", síntoma inequívoco de que se esperaban resistencias y fraudes, máxime en uno de los territorios que más apoyo brindaba al partido portugués y que hasta una fecha tan tardía como julio de 1476 no recibió orden expresa de recaudar el empréstito ${ }^{103}$.

${ }^{99}$ Contando la dobla de oro a $350 \mathrm{mrs}$ son $700 \mathrm{mrs}$ de cada marco, apreciado a $1850 \mathrm{mrs}$ según datos de la propia cuenta, lo cual suponía una reducción de la cantidad a pagar en plata, que originariamente debía ser la mitad de la atesorada.

100 El arcediano de Almazán sería enviado en 1478 desde Sevilla a Bayona junto al alcaide de Fuenterrabía Juan de Gamboa como embajador para entrevistarse con el obispo de Lumbiers y otro caballero, embajadores de Luis XI de Francia para tratar sobre la paz entre ambos reinos que el Cardenal trataba de establecer. PULGAR, F. DEL: Crónica de los Reyes Católicos..., Vol. I, Cap. XCIV, p. 331. Más adelante, el 20 de marzo de 1483 Pedro González de Mendoza tomaba posesión del arzobispado de Toledo a través de dos procuradores, uno de los cuales era precisamente Juan [López] de Medina, arcediano de Almazán en la iglesia de Sigüenza y vicario general en la misma, el cual también ocupaba en ese momento una canonjía en el cabildo toledano. LOP OTÍN, M.J.: El cabildo catedralicio de Toledo en el siglo XV. Aspectos institucionales y sociológicos, Madrid, Fundación Ramón Areces, 2006, p. 240. Sobre este personaje ver también NIETO SORIA, J.M.: Iglesia y génesis..., p. 444.

101 AGS, EMR, leg. 39, f. 128. Con estas declaraciones se elaboraría un inventario general para todo el obispado ordenado por el Cardenal. De su existencia da cuenta T. Minguella que, en su día, fue incapaz de localizarlo entre los fondos del Archivo Catedralicio de Sigüenza, a partir de la referencia al documento que realiza el deán Mariano Juárez a comienzos del siglo XIX. MINGUELLA Y ARNEDO, T.: Historia de la diócesis de Sigüenza y sus obispos, Madrid, Imprenta de la Revista de Archivos, Bibliotecas y Museos, 1912, Vol. 2, p. 174.

102 SANZ SANCHO, I.: op. cit., p. 1184.

103 AGS, RGS, julio de 1476, ff. 517 y 518. 
Lejos de solucionarse, el conflicto en el obispado de Sigüenza alcanzaría cotas de conflictividad cada vez más elevadas. En primer lugar porque muchos de los clérigos y mayordomos emplazados se negaron directamente a comparecer y prestar declaración jurada sobre la plata y rentas de fábrica de las iglesias a su cargo. A ello se suman los fraudes cometidos por una gran parte de los eclesiásticos que acudieron a Sigüenza y que -en palabras del receptor- "non declaravan como avían de declarar nin lo çierto", lo cual motivaría la apertura de procesos judiciales y el envío de "cartas denunçiadoras" y de excomunión contra estos clérigos, toda vez que el consenso en torno al empréstito se había revelado imposible. A estas medidas de presión se añadiría la remisión de cartas de entredicho sobre estas iglesias con las cuales se intentaba debilitar el apoyo que estos clérigos pudiesen recibir por parte de sus fieles ${ }^{104}$. No era la primera vez que la excomunión y el entredicho eran utilizados como arma política en el fragor del conflicto sucesorio y en relación con el expolio de bienes eclesiásticos, por otra parte censurado por la legislación canónica y sinodal desde antiguo: según la Crónica incompleta, el obispo de Salamanca ya había excomulgado en el otoño de 1475 a Alfonso V "y a quantos le seruian" en respuesta a la usurpación de la plata de la iglesia de Cantalapiedra -lugar de su señorío y su "cámara"- realizada por el monarca portugués tras hacerse con el control militar de la villa, lo cual prueba, además, la utilización de recurso planteado por el partido isabelino llevada a cabo por sus adversarios, aunque de forma mucho más limitada ${ }^{105}$. No obstante, el anónimo cronista procuraría en este caso recalcar la consideración sacrílega de la acción, merecedora no solo de censura eclesiástica a partir de lo dispuesto en la bula paulina que habilitaba a las iglesias castellanas para excomulgar "a los que sus lugares o rentas ocupasen", sino también de castigo divino ${ }^{106}$.

Una vez finalizadas las comparecencias en Sigüenza, el arcediano de Almazán remitiría como provisor nuevas cartas a todas las iglesias del obispado instando a la entrega efectiva del empréstito requerido "segund lo qu'el señor cardenal sobr'ello avía mandado", en las cuales se adjuntaba tanto el texto de la declaración que los responsables de cada iglesia habían realizado como una relación de la plata y dinero exigidos. Tampoco esta vez los mandatos surtirían el efecto esperado pues, una vez más, un gran número de iglesias se negó a satisfacer el empréstito, y las dispuestas a abonarlo, además de no acudir con la totalidad de las cantidades requeridas solicitaban prórrogas en el plazo asignado argumentando -según el receptor Gómez de

104 Sobre estas censuras eclesiásticas y su uso político en Castilla ver ARRANZ GUZMÁN, A.: "Excomunión eclesiástica y protesta ciudadana", en J.M. Nieto Soria (coord.), El conflicto en escenas. La pugna política como representación en la Castilla bajomedieval, Madrid, Sílex, 2010, pp. 247-278.

105 Ya señalamos en su momento cómo fray José de Sigüenza refiere la petición formulada por el arzobispo Carrillo de la plata de San Bartolomé de Lupiana, rechazada por el general de la orden. SIGÜENZA, J. DE: op. cit., Vol. II, pp. 13-14.

106 “[...] por tomar las cosas de la yglesia, como Cantalapiedra, que era cámara del obispo de Salamanca, le auian de seguir males; el qual por virtud de vna paulina que las yglesias de Castilla tenian para descomulgar a los que sus lugares o rentas ocupasen, descomulgó luego a don Alonso, rey que se llamaua de Castilla, y a quantos le seruian, y luego, en los dias que la paulina traya de plazo, puso entredicho papal en todos los lugares donde él y los suyos estouiesen, y de aquella hora en adelante, asi los clerigos con descomuniones y maldiçiones, como el rey y reyna con grand astuçia y diligençia, le guerrean por tantas partes, que nin valerse nin remediarse sabía". PUYOL, J. (ed.): Crónica incompleta de los Reyes Católicos (1469-1476), Madrid, Tipografía de Archivos, 1932, pp. 273-275. 
Córdoba- "que querían buscar dinero para poder pagar por non se desfazer de la plata de las iglesias".

No obstante, los problemas más importantes procederían de la amplificación política del conflicto a partir de la apelación de los mandamientos del Cardenal que realizaron ante el arzobispo de Toledo los arciprestazgos de Ayllón, Almazán, Caracena y Atienza, quizás fundamentada en la toma de partido que algunas de las fuerzas señoriales y militares de estos territorios habían realizado en favor de la opción portugue$\mathrm{sa}^{107}$. La circunstancia sería aprovechada hábilmente por Carrillo, que no tardaría en iniciar una particular lucha de poder apoyándose en la dependencia que la diócesis de Sigüenza, como sufragánea, tenía respecto del arzobispado de Toledo, cuyo titular era competente para sustanciar en grado de apelación los conflictos surgidos entre el clero de las diócesis que integraban la provincia eclesiástica bajo su jurisdicción ${ }^{108}$. En este caso, es evidente que la ampliación del conflicto respondía a una connivencia de intereses: por un lado los del clero parroquial seguntino, orientados fundamentalmente a la defensa del patrimonio de sus iglesias, y por otro, los de Carrillo, dispuesto a sacar provecho político del malestar generado por la exacción y a erigirse en defensor interesado de las libertades eclesiásticas socavadas por los partidarios de Isabel. De hecho, según refiere Hernando del Pulgar en una carta enviada a un caballero criado del arzobispo transmitida por Andrés Bernáldez, el prelado ya había mostrado anteriormente al cabildo de Toledo su oposición a la toma de plata ordenada por los reyes ${ }^{109}$, cuyo grado de aplicación en la sede toledana es por el momento desconocido.

Siguiendo el espíritu de las actuaciones emprendidas anteriormente por Pedro González de Mendoza, Alonso Carrillo remitiría a los arciprestazgos declarados en rebeldía tributaria nuevas cartas en las que, bajo pena de excomunión, ordenaba "que no pagasen cosa ninguna e a los jueces del cardenal que no entendiesen más en ello" en virtud de las competencias jurisdiccionales reconocidas por la legislación canónica al arzobispo toledano. La iniciativa no tardó en ser contestada por el Cardenal, que se apresuró a ordenar la apertura de procesos contra los mayordomos de las iglesias de los arciprestazgos refractarios a la medida, "fasta poner entredicho en cada una de las iglesias y en los mismos logares". La situación había llegado a tal punto de tensión que el propio receptor Gómez de Córdoba reconocía, en contra de los presupuestos asumidos por la propaganda isabelina, cómo la mayor parte de las iglesias del obispado "non querían venir nin enbiar a pagar si non con penas y escomuniones y

${ }^{107}$ Por ejemplo, el alcaide de Atienza Pedro de Almazán y Juan de Tovar, señor de Caracena, habían tomado partido por Alfonso V y, según Pulgar, "facían guerra en todas aquellas tierras e comarcas que estauan por el Rey e por la Reyna”. El propio Carrillo pararía en Atienza en su viaje desde Toro, donde se encontraba junto al rey de Portugal, hacia Alcalá de Henares. PULGAR, F. DEL: Crónica de los Reyes Católicos..., Vol. I, Cap. LXVIII, pp. 224-226.

${ }^{108}$ El análisis de esta dependencia, analizada a partir del caso del obispado de Cuenca, en DÍAZ IBÁÑEZ, J.: Iglesia, sociedad y poder en Castilla. El obispado de Cuenca en la Edad Media (siglos XII-XV), Cuenca, Alfonsípolis, 2003, pp. 502-506.

109 "Con todo eso, vi esta semana una carta que inviaba a su cabildo [el arzobispo Carrillo], en que reprehende mucho al rey y a la reina porque tomaron la plata de las iglesias, la cual sin duda estuviera segura en su sagrario si él estuviera quedo en su casa". BERNÁLDEZ, A.: Memorias del reinado de los Reyes Católicos, M. Gómez Moreno y J.M. Carriazo (eds.), Madrid, Real Academia de la Historia, 1962, Cap. XIII, p.36. 
entredichos, y se fallara e es notorio a todos que ninguna iglesia d'este obispado pagó con voluntad, sy non con premias y escomuniones", lo cual además exigió el constante envío de mensajeros con cartas "a unas partes e otras pues sy esto non se fiziera, e persona de recabdo y diligente allá non fuera, non se cobrara un solo maravedí".

Al margen de visiones apologéticas sobre el empréstito, es evidente que tanto el derecho canónico como las disposiciones sinodales castellanas y las bulas papales amparaban al clero diocesano seguntino en su resistencia. La constitución Quia celestis ya señalaba en 1322 -siguiendo los presupuestos de bulas como la Clericis laicos de Bonifacio VIII (1296) que reiteraban disposiciones del IV Concilio de Letrán-, la imposición de penas contra "los quebrantadores de la libertad de la santa madre Yglesia" y especialmente contra aquellos que tomasen o robasen los diezmos y cualesquier "otros bienes de las yglesias e de las personas eclesiásticas, de qualquier lugar estado o condición que fuesen" ${ }^{110}$. La misma defensa de la inmunidad de las propiedades y rentas eclesiásticas quedaría igualmente recogida en las disposiciones adoptadas en los concilios provinciales convocados por los arzobispos de Toledo a lo largo del siglo XIV -Peñafiel (1302), Alcalá de Henares (1326, 1333 y 1347) y Toledo (1339)-, en los cuales quedó establecida la pena de excomunión para los "raptores, invasores, vastatores, et depredatores bonorum eclesiarum vel clericorum", tal y como señalan explícitamente las actas del concilio alcalaíno de $1326^{111}$. De nuevo, y ya en una fecha mucho más próxima al empréstito, dos bulas otorgadas por Paulo II y Sixto IV en 1465 y 1475 respectivamente se encargaban de recordar la inviolabilidad del patrimonio y rentas eclesiásticas y el castigo canónico que de ello se seguiría ${ }^{112}$, tal y como ya había tenido ocasión de comprobar Alfonso V de Portugal en 1475.

De esta forma, la apelación realizada por las iglesias seguntinas derivó, no antes de abril de 1476, en la apertura de un proceso judicial sustanciado por Carrillo en su villa de Alcalá de Henares -el "pleito de Alcalá" referido en la cuenta dada por Gómez de Córdoba-, cuyo desarrollo concreto es completamente desconocido ${ }^{113}$. Se trataba de una maniobra inteligente ya que forzaba a los partidarios de Isabel -en este caso al Cardenal de España- a someterse al criterio de un tribunal eclesiástico y a reconocer implícitamente la superioridad de su jurisdicción en un asunto que, más allá de las

110 ARRANZ GUZMÁN, A.: op. cit., p. 256.

111 LOP OTÍN, M.J.: op. cit., pp. 120-122.

112 La bula de Paulo II, mencionada en la documentación como la "paulina", fue, por ejemplo, tomada en el claustro de la Universidad de Salamanca el 20 de junio de 1467, y publicada en la iglesia de Toledo el 20 de septiembre de 1467. BELTRÁN DE HEREDIA, V.: Cartulario de la Universidad de Salamanca (1218-1600), Salamanca, Ediciones Universidad de Salamanca, 2001, Vol. II, doc. 131, p. 58. LOP OTÍN, M.J.: op. cit., pp. 443 y 501. Más adelante los reyes, en sus instrucciones al obispo de Tuy, al abad de Sahagún y al doctor Juan Arias, embajadores en Roma ante Inocencio VIII, denunciaban el desorden provocado por la aplicación de las bulas "Paulina" y "Sixtina", y solicitaban su revocación "pues que las personas eclesiásticas tienen asaz remedios jurídicos e ordinarios para defension de sus personas e bienes mayormente, pues que las turbaciones de estos nuestros reinos dieron causa a las dichas bulas, e agora por la gracia de nuestro Señor hay tanta paz e justicia en ellos que las personas de todos estados de ellos, e mayormente los eclesiásticos alcanzan todo conplimiento de justicia". Colección de documentos inéditos para la historia de España, Madrid, Imprenta de la viuda de Calero, 1845, Vol VII, pp. 550-551. Ambas bulas junto a una "Calixtina" fueron revocadas finalmente por Inocencio VIII. AGS, PR, leg. 60, doc. 180/1.

${ }^{113}$ El pleito no se ha conservado o no ha podido ser localizado por el momento. 
razones económicas que lo habían motivado, evidenciaba las tensiones generadas en el seno de la Iglesia castellana tanto por el personalismo de las actuaciones políticas llevadas a cabo por prelados como Carrillo o González de Mendoza como por la supeditación de los intereses eclesiásticos a los del poder monárquico operada por los reyes ${ }^{114}$. En efecto, desde Sigüenza fueron enviados por tres veces procuradores a Alcalá con poderes del Cardenal, del arcediano de Almazán "y de los clérigos de la iglesia" con objeto de apelar las disposiciones incluidas en las cartas y mandamientos dados por el arzobispo de Toledo para que "los clérigos del açiprestadgo de Ayllón y de Atiença no pagasen cosa ninguna". El propio receptor Gómez de Córdoba justificaba la participación de los procuradores del Cardenal en el proceso abierto en Alcalá a partir del respeto a la legalidad eclesiástica pues, en caso contrario, los jueces seguntinos se exponían al envío de nuevas "cartas de ynibiçión" por parte de Carrillo a lo cual cabría añadir el uso propagandístico que el arzobispo podía realizar de la negativa a reconocer su jurisdicción como metropolitano en un asunto eclesiástico de su competencia. De hecho, y quizás en relación con el conflicto suscitado por el empréstito del obispado de Sigüenza u otros de semejante índole, Sixto IV ordenaba el 14 de julio de 1477 que ningún obispo sufragáneo impidiese las apelaciones al arzobispado toledano ${ }^{115}$, sancionando con ello la legalidad que se había visto obligado a reconocer el Cardenal Mendoza y las tensiones que existían entre el respeto a la jurisdicción eclesiástica, por un lado, y la sumisión a la voluntad regia que cabía esperar de los súbditos eclesiásticos del Reino. Con todo, el receptor reconocía cómo "el açiprestadgo de Ayllón non pagó cosa alguna nin se guardó en él los mandamientos nin entredicho puestos por el señor Cardenal", evidenciando la comunión de intereses forjada entre el clero diocesano de determinados distritos seguntinos y los intereses políticos del arzobispo de Toledo. No obstante, las censuras eclesiásticas establecidas por parte del Cardenal Mendoza, a excepción de los territorios declarados abiertamente en rebeldía -como el distrito de Ayllón-, parece que mostraron, a la postre, cierta eficacia. En este sentido, no conviene perder de vista que, a pesar de las resistencias, fraudes y de que todo se pagara -a decir de Gómez de Córdoba"por fuerça y por descomuniones y penas", el rendimiento total del empréstito en el obispado seguntino ascendió a algo más de un millón de mrs, cantidad más que razonable máxime cuando otras diócesis como la abulense, donde no hay constancia de resistencias, lograron reunir millón y medio de $\mathrm{mrs}^{116}$.

114 Tal y como ha señalado el profesor Nieto Soria, la intervención de eclesiásticos en el conflicto sucesorio responde fundamentalmente a la plasmación de posiciones políticas individualizadas en el marco de los intereses expresados por linajes o ligas nobiliarias, sin que ello permita hablar de una división institucional de la Iglesia castellana a partir de la formación de un frente común dotado de un proyecto político-religioso enunciado de forma precisa. NIETO SORIA, J.M.: Iglesia y génesis..., pp. 286-288.

115 Archivo Capitular de Toledo, X.1.B.1.1. Cit. DÍAZ IBÁÑEZ, J.: op. cit., p. 504.

116 Según la cuenta del empréstito del obispado de Ávila se cobraron aproximadamente 554 marcos de plata los cuales, tasados a $1.870 \mathrm{mrs}$ el marco (tal y como consta en la cuenta de la plata de Sigüenza), arrojarían un total de $1.035 .980 \mathrm{mrs}$. A ellos se suman otros $438.550 \mathrm{mrs}$ cobrados en dinero, lo cual ofrece un total de 1.474.530 mrs. AGS, EMR, leg. 43, f. 73. Si tomamos como baremo la aportación de cada diócesis en el subsidio otorgado por Sixto IV en 1482 para financiar la guerra de Granada, la proporción entre Ávila y Sigüenza sería la siguiente: Ávila contribuyó con 3.316 florines, y Sigüenza con 2.415. De esta forma la relación es de 1-0,73. Si aplicamos la misma proporción tomando como 
A pesar de la importancia del conflicto jurídico abierto y de la notable profusión con que ambos partidos recurrieron a la excomunión y el entredicho como instrumento de presión para hacer efectivas sus posiciones, Fernando e Isabel abrieron a partir de junio de 1476, cuando la toma de plata ya se había consumado en numerosos territorios, una nueva vía para dotar de legitimidad la exacción ordenada a partir de la negociación diplomática con el papa, en última instancia el único que podía aportar un cauce legitimador definitivo a una medida unilateral que, en función de la falta de respaldo pontificio, siempre podría ser considerada desde la óptica de la usurpación. Por ello, uno de los puntos incluidos en las instrucciones dadas el cinco de junio de 1476 al alcalde García Martínez de Lerma, embajador en Roma, se refiere explícitamente a la cuestión de la plata y dinero tomados de iglesias y monasterios "para socorro de nuestras nesçesidades" 117 .

Ante una situación censurada de forma abierta por la legislación eclesiástica y las disposiciones pontificias, cuya legitimidad "de origen" no podía ser invocada desde el punto de vista del derecho canónico, los reyes optarían por la construcción de una legitimidad "de ejercicio" basada en la reafirmación del compromiso adquirido de facilitar la devolución del empréstito con cargo a los 30 millones de mrs apartados con este fin en el servicio aprobado en las Cortes de Madrigal. Con objeto de garantizar la percepción efectiva del servicio en todos los territorios y evitar las resistencias fiscales que pudiesen plantear los partidarios de Alfonso V, García Martínez de Lerma solicitaría de Sixto IV la concesión de una bula que habilitase el establecimiento de penas canónicas contra las personas eclesiásticas y seglares que entorpeciesen la recaudación de estos 30 millones, aplicadas en última instancia por los titulares de cada diócesis. De esta forma, tanto el papa como el episcopado castellano quedarían involucrados en el proceso de restitución del empréstito, lo cual contribuiría de forma indirecta a sancionar la necesidad de la causa que lo había motivado. No obstante, la instrucción más relevante se refiere explícitamente a la legitimación por vía indirecta de la toma de plata que, "por sanidad de nuestras conçiençias", los reyes buscaban. Conscientes de que el empréstito suponía un atentado contra la inmunidad de la Iglesia susceptible de recibir legítima censura eclesiástica, los reyes solicitaban de Sixto IV la absolución de cualquier excomunión en que hubiesen incurrido tanto ellos como los prelados y otras personas eclesiásticas o seglares implicadas "en qualquier manera en el dicho enpréstydo" lo cual, más allá de aportar un cauce legitimador al hecho fiscal, permitiría neutralizar los instrumentos de presión religiosa desplegados por prelados como Carrillo ${ }^{118}$.

base la cantidad total cobrada en Ávila $(1.474 .530 \mathrm{mrs})$ el total de Sigüenza debería haber ascendido a 1.076.407 mrs, cantidad bastante próxima a la recaudada realmente. Los datos del subsidio de 1482 en LADERO QUESADA, M.Á.: La Hacienda Real..., p. 237.

117 La instrucción en AGS, PR, leg. 16, doc. 56. Ed. SUÁREZ FERNÁNDEZ, L.: Política internacional de Isabel La Católica. Estudio y documentos, Valladolid, Universidad de Valladolid, 1965, Vol. I, doc. 26, p. 320.

118 Aunque desconocemos la evolución del pleito de Alcalá es probable que los impedimentos del prelado toledano remitiesen parcialmente una vez firmado el 13 de septiembre de 1476 el acuerdo por el cual se comprometía a prestar obediencia a Isabel y Fernando y a cesar en su apoyo al partido portugués. AZCONA, T. DE: op. cit., pp. 307-308. 


\subsection{LA LENTA RESTITUCIÓN DEL EMPRÉSTITO}

Al igual que había sucedido en la toma de 1429 , el reembolso de la plata y rentas de fábrica percibidas entre 1475 y 1476 no seguiría el ritmo esperado, a pesar de las garantías expresadas por los reyes ante el papa, de la articulación de mecanismos de control del proceso de devolución a partir del encargo dado a los priores de los monasterios jerónimos del Reino de recabar información sobre "si esta plata se restituya enteramente", y del interés de la propaganda oficial -representada por Pulgar- por expresar la gran diligencia mostrada por Isabel para que la devolución se "fiziese cunplidamente" 119 . El propio fray Hernando de Talavera, inductor de la medida, sería uno de los primeros en expresar en la ya mencionada carta escrita el 15 de septiembre de 1477 desde el monasterio vallisoletano de Prado el descontento de la clerecía -y el suyo propio como "el primero que firmo que podrian prestarlo"- al señalar el clamor de las iglesias "por la paga de la plata" ${ }^{20}$. A ello seguiría el recordatorio realizado a los reyes por parte de los eclesiásticos reunidos en el concilio nacional de Sevilla celebrado en 1478, donde quedó expresada la necesidad de acometer la restitución del empréstito, iniciada poco después en algunas diócesis: por ejemplo, en el obispado de Jaén, cuyas iglesias debían recibir 600.000 mrs del prior de San Jerónimo de Valparaíso - encargado de organizar los pagos con el dinero mandado librar el 20 de agosto del mismo año por el tesorero Francisco Núñez-, las devoluciones darían comienzo a partir de marzo de 1479, aunque en algunos casos, como el de las iglesias del Adelantamiento de Cazorla, el reembolso no se produciría de forma efectiva hasta $1482^{121}$. Igualmente, la devolución de las cantidades prestadas en el obispado de Córdoba se llevaría a cabo en su mayor parte entre enero y febrero de $1479^{122}$.

Resulta imposible determinar la procedencia exacta de estas cantidades, aunque es evidente que los 30 millones de mrs del servicio extraordinario aprobado en 1476 se revelaron claramente insuficientes para restituir la totalidad del empréstito. Por ello, una vez consolidados en el trono, los reyes autorizarían el libramiento de distintos pagos con cargo a las rentas ordinarias del Reino destinados a la devolución de la plata. Ya en 1480 consta el reembolso de 280.300 mrs al obispo de Córdoba Alonso de Burgos por la plata y dineros prestados ${ }^{123}$, aunque desconocemos si esta cantidad se refiere a un préstamo realizado a título personal o tiene que ver, por el contrario, con el empréstito de las iglesias de su diócesis. Al año siguiente, según carta de los reyes dada en julio de 1481, Luis de Alcalá, importante financiero, recibía orden de pagar al judío Rabí Mayr 1.000.000 mrs procedentes de las alcabalas y tercias del maestrazgo de Calatrava "para la plata que nos tomamos prestada de çiertas yglesias

119 PULGAR, F. DEL: Crónica de los Reyes Católicos..., pp. 145-146.

120 BNE, Mss. 1104, ff. 62-63. Cit. AZCONA, T. DE: op. cit., p. 301. La interpretación que hacemos del documento difiere de la realizada por Azcona, que ve en esta expresión un elemento más para defender la "ortodoxia del procedimiento isabelino".

121 SANZ SANCHO, I.: op. cit., pp. 1178-1182.

122 Ibídem, p. 1185.

123 NIETO SORIA, J.M.: Iglesia y génesis..., p. 341. LADERO QUESADA, M.Á.: La Hacienda Real.., p. 291. 
e monasterios d'estos nuestros regnos e señoríos"124. De nuevo, en 1482, el "apuntamiento" de libranzas en rentas ordinarias señala el pago proyectado de otro millón de mrs con el mismo fin, al que también contribuiría, según parece, parte de la moneda forera recaudada ese año ${ }^{125}$. A estas cantidades se suman otras. Por ejemplo, el millón de maravedíes librado el 20 de mayo de 1484 en las rentas ordinarias de los partidos de Jerez, orden de Calatrava, Ciudad Real y los señoríos del arzobispado de Toledo en favor de fray Hernando de Talavera, prior de Prado, para su entrega a ciertas iglesias "de la plata que prestaron a Sus Altezas del año pasado de LXXV años"126; o los 2.455 .724 mrs pagados por el tesorero Gonzalo de Baeza en 1484 y 1487 con idéntico fin ${ }^{127}$. Finalmente, según denunciaba el obispo de Calahorra Juan de Ortega, todavía en una fecha tan tardía como 1500 seguían sin ser reembolsados 80 marcos de plata procedentes de ciertos cálices y cruces tomados por el conde de Treviño en las iglesias de la ciudad ${ }^{128}$.

\section{CONCLUSIÓN}

Más allá de la importancia que la devolución efectiva de estos empréstitos tenía en la construcción de una legitimidad "de ejercicio" tendente a limitar la conceptualización de la exacción como expolio o acto sacrílego y a facilitar su aceptación entre el clero, los desarrollos doctrinales sobre los cuales se fundamentaba su legitimidad "de origen" unidos, por una parte, a la propaganda regia destinada a lograr la adhesión y respaldo del estamento eclesiástico a una medida que atentaba de forma expresa contra la inmunidad y libertad de la Iglesia y, por otra, a la problemática asociada a su cobro efectivo en contextos conflictivos, permiten valorar la dimensión alcanzada por la extensión del poder soberano de la Monarquía sobre la Iglesia castellana en materia fiscal, traducida en la supeditación del patrimonio eclesiástico a los intereses

124 Rabí Mayr solicitaría, para evitar demoras como consecuencia de las "escusas e dilaçiones" que pudiese poner Luis de Alcalá a la hora de afrontar el pago, autorización para repartir el millón de mrs en las alcabalas de Almagro y el resto de villas y lugares del Campo de Calatrava de 1481 "por los mrs del terçio primero". AGS, EMR, leg. 31, f. 257. El apuntamiento de libranzas del año 1481 refiere el pago proyectado de $1.000 .000 \mathrm{mrs}$ para la plata de las iglesias. LADERO QUESADA, M.Á.: La Hacienda Real..., p. 298.

${ }^{125}$ Ibídem, p. 300. Las cuentas de la moneda forera del obispado de Sigüenza y los arcedianazgos de Guadalajara, Madrid, Toledo, Talavera, Calatrava y Alcaraz no refieren explícitamente partidas destinadas al pago de la plata prestada por las iglesias. AGS, EMR, leg. 32, f. 112; leg. 33, ff. 231, 236 y 239-240. Sin embargo constan libranzas en favor de fray Hernando de Talavera (el "prior de Prado" en la documentación) en la moneda forera de los arcedianazgos de Toledo (153.150 mrs), Talavera (31.638 mrs), Calatrava (70.500 mrs) y Alcaraz ( $83.862 \mathrm{mrs})$, quizás destinadas a la devolución del empréstito. AGS, EMR, leg. 33, f. 230, 233-234 y 237-238.

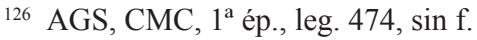

127 En 1484 se libraban en el tesorero $80.762 \mathrm{mrs}$ a Alonso de Valdivieso para el pago de la plata prestada por la Iglesia de Santa María la Mayor y el monasterio de San Francisco, mientras que en 1487 Gonzalo de Baeza entregaba 1.200.000 mrs al monasterio de Santa María de Prado, y otros 1.174.962 mrs al de Frex del Val para la restitución de la plata tomada en los obispados de Burgos y Palencia. AZCONA, T. DE: op. cit., p. 303.

128 NIETO SORIA, J.M.: Iglesia y génesis..., p. 341. AZCONA, T. DE: op. cit., p. 303. 
formulados en determinados momentos desde el poder monárquico a partir de la consideración de ideas globalizadoras como la "necesidad" o el "bien común" del Reino que, además de sostener la virtud de la causa que motivaba la exacción, contribuían a facilitar su difusión y aceptación.

En este sentido, la experiencia de la toma de plata y rentas de fábrica de los años 1475-1476, sobre la base previa representada por el empréstito de 1429, se reveló determinante en la definición de la Monarquía como poder legitimado para disponer excepcionalmente de los bienes eclesiásticos a partir de la aplicación de principios jurídico-políticos como el vínculo de naturaleza o el organicismo que, según los presupuestos desarrollados desde la esfera monárquica, obligaban a la clerecía a acudir con los medios económicos a su alcance en defensa del rey como señor natural y cabeza de la comunidad política del Reino. No obstante, el reconocimiento de esta supeditación requería de otro tipo de justificaciones tendentes a generar consenso en torno a una medida censurada por el papado y la legislación sinodal castellana. Para ello se recurriría a una valoración especialmente positiva de las consecuencias que cabía esperar de la colaboración económica de la Iglesia del Reino con la Monarquía en la financiación de causas políticas, como el conflicto sucesorio, amparadas por discursos impregnados de un fuerte carácter teológico-religioso. De este modo, la colaboración material de la Iglesia castellana con la causa isabelina, además de ratificar una legitimidad procedente de la propia divinidad, redundaría en beneficio de los bienes eclesiásticos en función de la especial protección dispensada por los monarcas a la Iglesia del Reino, idea explicitada por los propios reyes en 1478 una vez que el empréstito ya se había consumado ${ }^{129}$. En este contexto, las resistencias planteadas a la exacción por parte del clero parroquial de determinados territorios -tal y como ha quedado expresado a partir del estudio del caso de Sigüenza- no parecen responder tanto a la definición de criterios de actuación institucionales tendentes a limitar o poner en cuestión de forma consciente o intencional la dimensión fiscal de este proceso, como a la connivencia existente entre los intereses eclesiásticos particulares -fundamentalmente de tipo económico- expresados por el clero local y la línea de actuación política de prelados como Alonso Carrillo, definida a partir de la fidelidad prestada al partido portugués en virtud de intereses personales inmediatos.

Al cabo, los elementos legitimadores del empréstito eclesiástico ordenado en 1475-1476 (justicia y necesidad de la causa impositionis, compromiso firme de devolución...), más allá de su proyección jurídica posterior derivada de su inclusión en compilaciones legislativas próximas al hecho fiscal-como las Ordenanzas Reales de Castilla (1484)- o mucho más lejanas -como la Novísima Recopilación de Leyes ${ }^{130}$, tendrían su reflejo en proyectos de financiación de la contienda granadina como el recogido en el llamado Memorial del fraile Blanco, redactado probablemente en los momentos previos al inicio de la guerra final contra el emirato ${ }^{131}$. En él, su anónimo autor proponía a la reina la toma sin "ningund cargo de conçiençia" de las riquezas

${ }^{129}$ NIETO SORIA, J.M.: Iglesia y génesis..., p. 343.

${ }^{130}$ Novísima Recopilación de las leyes de España, Madrid, 1805. Libro I, Titulo V, ley VIII. Según se indica, la ley procede de los ordenamientos de las Cortes de Burgos de 1409 y Zamora de 1432.

131 LADERO QUESADA, M.Á.: Castilla y la conquista del Reino de Granada, Valladolid, Universidad de Valladolid, 1967, p. 215. 
custodiadas en distintos monasterios castellanos, entre los cuales destacaba explícitamente el de San Benito de Valladolid -de donde podrían obtenerse unos veinte o veinticinco millones de mrs- junto a algunas de las comunidades jerónimas más importantes del Reino como Guadalupe, San Bartolomé de Lupiana, San Isidoro del Campo, San Jerónimo de Sevilla y Santa María de las Cuevas. Más allá del ya tradicional compromiso de restituir las cantidades tomadas, la medida encontraba adecuación en los marcos políticos e ideológicos expresados anteriormente en virtud de la potencialidad de estas riquezas para sufragar una causa "santa e laudable" y del escaso servicio que las cantidades atesoradas "en las arcas" prestaban "a Dios, nin a su fe, ni a las gentes" 132 . No obstante, esta vez la medida no fue puesta en marcha pues, a pesar de la subordinación de la Iglesia castellana a la soberanía regia exigida por Isabel y Fernando, gran parte de las cantidades tomadas en 1475-1476 seguían sin ser restituidas y no convenía, en el nuevo contexto que se abría, romper el consenso logrado en torno a la legitimidad de una de las fuentes de financiación que había contribuido al triunfo militar y político de la opción isabelina en el conflicto sucesorio.

${ }^{132}$ AGS, CCA, Diversos, leg. 44, f. 1. 